\title{
Surface Modification Techniques for Biomedical Grade of Titanium Alloys: Oxidation, Carburization and Ion Implantation Processes
}

\author{
S. Izman ${ }^{1}$, Mohammed Rafiq Abdul-Kadir ${ }^{1}$, Mahmood Anwar' ${ }^{1}$, \\ E.M. Nazim ${ }^{1}$, R. Rosliza ${ }^{2}$, A. Shah ${ }^{1}$ and M.A. Hassan ${ }^{1}$ \\ ${ }^{1}$ Universiti Teknologi Malaysia, UTM Skudai, Johor, \\ ${ }^{2}$ TATi University College, Malaysia, Kemaman, Terengganu, \\ Malaysia
}

\section{Introduction}

Titanium and titanium alloys are widely used in a variety of engineering applications, where the combination of mechanical and chemical properties is of crucial importance. Aerospace, chemical and automotive industries as well as the medical device manufacturers also benefited from the outstanding properties of titanium alloys. The wide spread of its uses in biomedical implants is mainly due to their well-established corrosion resistance and biocompatibility. However, not all titanium and its alloys can meet all of the clinical requirements for biomedical implants. For instance, it is reported that bare titaniumvanadium alloy has traces of vanadium ion release after long period exposure with body fluid (López et al., 2010). Excessive metal ions release into the body fluid and causes toxicity problems to the host body. A new group of titanium alloy such as $\mathrm{Ti}-\mathrm{Nb}$ and $\mathrm{Ti}-\mathrm{Zr}$ based are recently introduced in the market to overcome the toxicity of titanium-vanadium based alloy (Gutiérrez et al., 2008). Although, these alloys have a high strength to weight ratio and good corrosion resistance and biocompatible, but it suffers from poor tribological properties which limits their usefulness to a certain extent especially when they are applied to joint movements. Wear debris generated from these articulation joints can induce inflammation problem and toxic effect to the human body. In biomedical point of view, post implantation is very crucial stage where the interaction between the implanted material surface and the biological environment in human body is critically evaluated. Either in the short or long run, the toxic effect becomes an issue to host body. Hence, the implant material surface has a strong role in the responses to the biological environment. In order to improve the biological and tribological properties of implant materials, surface modification is often required (Huang et al., 2006, Kumar et al., 2010b). This chapter embarks on the commonly used implant biomaterials, followed by general overview on the surface modification techniques for treating titanium alloy. The basic principles of oxidation, carburization and ion implantation methods and their developments are discussed in the following sections. 


\section{Implant biomaterials}

Biomedical implant is defined as an artificial organ used for restoring the functionality of a damaged natural organ or tissue of the body (Liu et al., 2004). In other words it is expected to perform the functions of the natural organ or tissue without adverse effect to other body parts (Andrew et al., 2004). Fig.1 shows a typical hip and knee joint implants replacement. Biomedical engineering is a new discipline where engineering principles and design concepts are applied to improve healthcare diagnosis, monitoring and therapy by solving medical and biological science related problems. At least three different terminologies that always are being referred to biomedical implant materials, i.e. biocompatibility, biodegradable and biomaterials. Biocompatibility is defined as the immune rejection or inflammatory responses of the surrounding tissue systems to the presence of a foreign object in the body. Whereas biodegradable material means the implant material can easily decompose in the body. Their presence in the body is temporary and usually they degrade as a function of time, temperature or pressure. Biomaterials must possess biocompatibility and sometimes biodegradable properties. A typical example of simultaneously possess biocompatibility and biodegradable properties is drug delivery capsule where their presence to release drugs inside the body over a specific time without causing any toxic effect to the surrounding tissues (Hollinger, 2006). There are varieties of biomaterials such as metallic, ceramics and polymers that have been used as biomedical devices. Metallic biomaterials can be grouped as steels, cobalt and titanium based alloys. Among non-metallic polymeric based biomaterials are polyethylene terephthalate, polytetrafluoroethylene, ultrahigh molecular weight polyethylene (UHMWPE) and lactide-co-glycolide. While titania $\left(\mathrm{TiO}_{2}\right)$, titanium carbide (TiC), titanium nitride (TiC), bioglass, hydroxyapatite (HA), silicon carbide $(\mathrm{SiC})$ are typical examples of ceramic biomaterials. All biomaterials must be free from cytotoxicity. Plain steel would corrode easily in the body and become toxic. On the

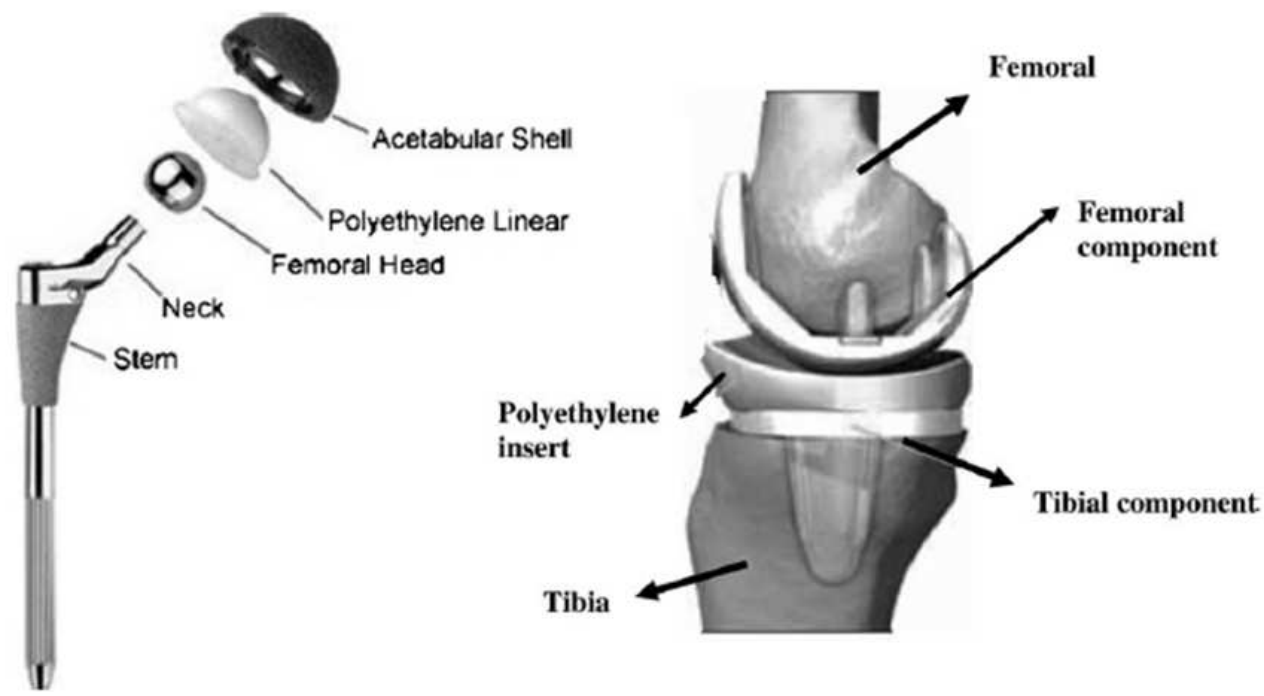

Fig. 1. Total hip and knee implants replacements (Geetha, 2009) 
other hand, biomedical grade 316L stainless steel possesses higher biocompatibility properties and it can be used as implant as well as for surgical devices. However, due to its heavy weight, this group of materials have been gradually replaced by other lighter biomaterials such as titanium alloys. Co based alloys is another metallic biomaterials but its high elastic modulus compared to bone causes stress shielding effect especially in load bearing applications (Kumar et al., 2010b). Stress shielding effect is the reduction of bone density due to the removal of normal stress from bone by an implant. Among metallic materials, titanium and its alloys are considered as the most convincing materials in medical applications nowadays because they exhibit superior corrosion resistance and tissue acceptance when compared to stainless steels and Co-based alloys. Table 1 shows the various metallic biomaterials used for medical applications.

\begin{tabular}{|c|c|c|c|}
\hline Material designation & $\begin{array}{l}\text { Common } \\
\text { or trade name }\end{array}$ & \begin{tabular}{|l} 
ASTM \\
Standard
\end{tabular} & \begin{tabular}{|l} 
ISO \\
Standard
\end{tabular} \\
\hline \begin{tabular}{|l} 
Steel biomaterial : \\
Fe-18Cr-14Ni-2.5Mo \\
Fe-18Cr-12.5Ni-2.5Mo,Cast \\
Fe-21Cr-10Ni-3.5Mn-2.5Mo \\
Fe-22Cr-12.5Ni-5Mn-2.5Mo \\
Fe-23Mn -21Cr-1Mo-1N
\end{tabular} & $\begin{array}{l}\text { 316L Stainless Steel } \\
\text { 316L Stainless Steel } \\
\text { REX 734 } \\
\text { XM-19 } \\
108\end{array}$ & $\begin{array}{l}\text { ASTM F } 138 \\
\text { ASTM F } 745 \\
\text { ASTM F } 1586 \\
\text { ASTM F } 1314 \\
\text { F-04.12.35 }\end{array}$ & $\begin{array}{l}\text { ISO 5832-1 } \\
- \\
\text { ISO 5832-9 } \\
- \\
-\end{array}$ \\
\hline \begin{tabular}{|l|} 
Cobalt base biomaterials: \\
Co-28Cr-6Mo Casting alloy \\
Co-28Cr-6Mo Wrought alloy\#1 \\
Co-28Cr-6Mo Wrought alloy\#2 \\
Co-28Cr-6Mo Wrought alloy\#3 \\
Co-20Cr-15W-10Ni-1.5Mn \\
Co-20Ni-20Cr-5Fe-3.5Mo-3.5W-2Ti \\
Co-19Cr-7Ni -14Fe-7Mo-1.5W-2Ti \\
Co-20Cr-15Ni -15Fe-7Mo-2Mn \\
Co-35Ni-20Cr-10Mo
\end{tabular} & $\begin{array}{l}\text { Cast CoCrMo } \\
\text { Wrought CoCrMo, Alloy } 1 \\
\text { Wrought CoCrMo, Alloy } 2 \\
\text { Wrought CoCrMo,GADS } \\
\text { L-605 } \\
\text { Syncoben } \\
\text { Grade 2 "Phynox" } \\
\text { Grade 1 "Elgiloy" } \\
35 \mathrm{~N}\end{array}$ & $\begin{array}{l}\text { ASTM F } 75 \\
\text { ASTM F } 1537 \\
\text { ASTM F } 1537 \\
\text { ASTM F } 1537 \\
\text { ASTM F } 90 \\
\text { ASTM F } 563 \\
\text { ASTM F } 1058 \\
\text { ASTM F } 1058 \\
\text { ASTM F } 562\end{array}$ & $\begin{array}{l}\text { ISO } 5832-4 \\
\text { ISO } 5832-12 \\
\text { ISO } 5832-12 \\
- \\
\text { ISO } 5832-5 \\
\text { ISO } 5832-8 \\
\text { ISO } 5832-7 \\
\text { ISO } 5832-7 \\
\text { ISO } 5832-6\end{array}$ \\
\hline $\begin{array}{l}\text { Titanium base biomaterials: } \\
\text { Ti Cp-1 } \\
\text { Ti CP-2 } \\
\text { Ti-3Al-2.5V } \\
\text { Ti-5Al-2.5Fe } \\
\text { Ti-6Al-4V } \\
\text { Ti-6Al-4V ELI } \\
\text { Ti-6Al-7Nb } \\
\text { Ti-15Mo } \\
\text { Ti-12Mo-6Zr-2Fe } \\
\text { Ti-11.5Mo-6Zr-4.5Sn } \\
\text { Ti-15Mo-5Zr-3Al } \\
\text { Ti-13Nb-13Zr } \\
\text { Ti-35Nb-7Zr-5Ta } \\
\text { Ti-45Nb }\end{array}$ & 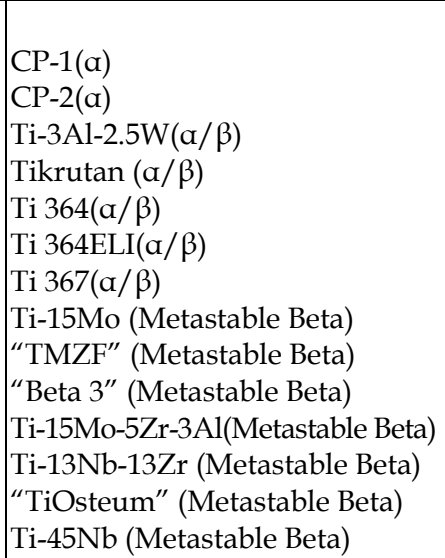 & $\begin{array}{l}\text { ASTM F } 67 \\
\text { ASTM F } 67 \\
\text { ASTM F } 2146 \\
- \\
\text { ASTM F } 1472 \\
\text { ASTM F } 136 \\
\text { ASTM F } 1295 \\
\text { ASTM F } 2066 \\
\text { ASTM F } 1813 \\
- \\
- \\
\text { ASTM F } 1713 \\
- \\
\text { ASTM B } 348\end{array}$ & $\begin{array}{l}\text { ISO 5832-2 } \\
\text { ISO 5832-2 } \\
- \\
\text { ISO 5832-10 } \\
\text { ISO 5832-3 } \\
\text { ISO 5832-3 } \\
\text { ISO } 5832-11 \\
- \\
- \\
- \\
\text { ISO 5832-14 } \\
-\end{array}$ \\
\hline
\end{tabular}

Table 1. Metallic biomaterials for medical and surgical implants (Courtesy from ATI, Allvac, USA) 


\section{Overview of surface modification techniques}

Since all biomedical devices subject to extremely high clinical requirements, a thorough surface modification process is needed prior to implantation process into the human body. The main reasons to carry out various surface modification processes on implant materials for biomedical applications can be summarized as follows:

i. Clean implant material surface from contaminations prior to implantation

ii. Increase bioactivity, cell growth and tissue attachments after implantation

iii. Increase hardness of implant to reduce wear rate especially in articulation joint applications

iv. Introduce passive layer to prevent excessive ion release into body environment

v. Promote antibacterial effect

vi. Increase fatigue strength of implants

The proper surface modification techniques keep the excellent bulk attributes of titanium alloys, such as good fatigue strength, formability, machinability and relatively low modulus. It also improves specific surface properties required by different clinical requirements. Table 2 summarizes the typical surface modification schemes used to treat titanium and its alloys for implant.

\begin{tabular}{|c|c|c|}
\hline $\begin{array}{l}\text { Surface modification } \\
\text { methods }\end{array}$ & Modified layer & Objective \\
\hline 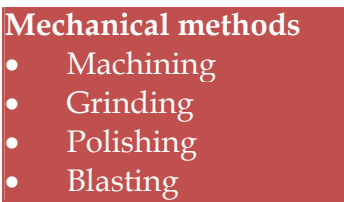 & $\begin{array}{l}\text { Rough or smooth surface } \\
\text { formed by subtraction process }\end{array}$ & $\begin{array}{l}\text { Produce specific surface } \\
\text { topographies; clean and roughen } \\
\text { surface; improve } \\
\text { adhesion in bonding }\end{array}$ \\
\hline Chemical methods & & \\
\hline $\begin{array}{ll}\text { - } & \text { Acidic } \\
\text { treatment } \\
\text { - } \\
\text { Alkaline } \\
\text { treatment }\end{array}$ & $\begin{array}{l}<10 \mathrm{~nm} \text { of surface oxide layer } \\
\sim 1 \mu \mathrm{m} \text { of sodium titanate gel }\end{array}$ & $\begin{array}{l}\text { Remove oxide scales and } \\
\text { contamination } \\
\text { Improve biocompatibility, } \\
\text { bioactivity or bone conductivity }\end{array}$ \\
\hline $\begin{array}{l}\text { Hydrogen } \\
\text { peroxide } \\
\text { treatment } \\
\end{array}$ & $\begin{array}{c}\sim 5 \mathrm{~nm} \text { of dense inner oxide and } \\
\text { porous outer layer }\end{array}$ & $\begin{array}{l}\text { Improving biocompatibility, } \\
\text { bioactivity or bone conductivity }\end{array}$ \\
\hline Sol-gel & $\begin{array}{l}\sim 10 \mu \mathrm{m} \text { of thin film, such as } \\
\text { calcium phosphate, } \mathrm{TiO}_{2} \text { and } \\
\text { silica }\end{array}$ & $\begin{array}{l}\text { Improve biocompatibility, } \\
\text { bioactivity or bone conductivity }\end{array}$ \\
\hline Anodic oxidation & $\begin{array}{l}\sim 10 \mathrm{~nm} \text { to } 40 \mu \mathrm{m} \text { of } \mathrm{TiO}_{2} \text { layer, } \\
\text { adsorption and incorporation of } \\
\text { electrolyte anions }\end{array}$ & $\begin{array}{c}\text { Produce specific surface } \\
\text { topographies; } \\
\text { improved corrosion resistance; } \\
\text { improve } \\
\text { biocompatibility, bioactivity or } \\
\text { bone conductivity }\end{array}$ \\
\hline
\end{tabular}




\begin{tabular}{|c|c|c|}
\hline $\begin{array}{c}\text { CVD } \\
\text { (Chemical Vapour } \\
\text { Deposition) }\end{array}$ & $\begin{array}{l}\sim 1 \mu \mathrm{m} \text { of } \mathrm{TiN}, \mathrm{TiC}, \mathrm{TiCN}, \\
\text { diamond and diamond-like } \\
\text { carbon thin film }\end{array}$ & $\begin{array}{l}\text { Improve wear resistance, } \\
\text { corrosion } \\
\text { resistance and blood } \\
\text { compatibility }\end{array}$ \\
\hline Biochemical methods & $\begin{array}{l}\text { Modification through silanized } \\
\text { titania, photochemistry, self- } \\
\text { assembled monolayers, protein- } \\
\text { resistance, etc. }\end{array}$ & $\begin{array}{l}\text { Induce specific cell and tissue } \\
\text { response } \\
\text { by means of surface- } \\
\text { immobilized } \\
\text { peptides, proteins, or growth } \\
\text { factors }\end{array}$ \\
\hline $\begin{array}{ll}\text { Physical methods } \\
\text { - } & \text { Thermal spray } \\
\text { - } & \text { Flame spray } \\
\text { - } & \text { HVOF } \\
\text { - } & \text { DGUN } \\
\end{array}$ & $\begin{array}{l}\sim 30 \text { to } 200 \mu \mathrm{m} \text { of coatings, such } \\
\text { as } \\
\text { titanium, } \mathrm{HA} \text {, calcium silicate, } \\
\mathrm{Al}_{2} \mathrm{O}_{3}, \mathrm{ZrO}_{2}, \mathrm{TiO}_{2}\end{array}$ & $\begin{array}{l}\text { Improve wear resistance, } \\
\text { corrosion } \\
\text { resistance and biological } \\
\text { properties }\end{array}$ \\
\hline $\begin{array}{l}\text { PVD (Physical Vapour } \\
\text { Deposition) } \\
\text { Evaporation } \\
\text { - } \quad \text { Ion plating } \\
\text { - } \quad \text { Sputtering } \\
\end{array}$ & $\begin{array}{l}\sim 1 \mu \mathrm{m} \text { of } \mathrm{TiN}, \mathrm{TiC}, \mathrm{TiCN}, \\
\text { diamond and diamond-like } \\
\text { carbon thin film }\end{array}$ & $\begin{array}{l}\text { Improve wear resistance, } \\
\text { corrosion } \\
\text { resistance and blood } \\
\text { compatibility }\end{array}$ \\
\hline $\begin{array}{l}\text { Ion implantation and } \\
\text { deposition } \\
\text { - Beam-line ion } \\
\text { implantation } \\
\text { - } \quad \text { PIII } \\
\end{array}$ & $\begin{array}{l}\sim 10 \mathrm{~nm} \text { of surface modified } \\
\text { layer and/or } \sim \mu \mathrm{m} \text { of thin film }\end{array}$ & $\begin{array}{l}\text { Modify surface composition; } \\
\text { improve wear, corrosion } \\
\text { resistance, and biocompatibility }\end{array}$ \\
\hline $\begin{array}{l}\text { Glow discharge plasma } \\
\text { treatment }\end{array}$ & $\begin{array}{l}\sim 1 \mathrm{~nm} \text { to } \sim 100 \mathrm{~nm} \text { of surface } \\
\text { modified layer }\end{array}$ & $\begin{array}{l}\text { Clean, sterilize, oxide, nitride } \\
\text { surface; remove native oxide layer }\end{array}$ \\
\hline
\end{tabular}

Table 2. Summary of surface modification methods used for titanium and its alloys implants (Liu et al., 2004)

Among the popular surface modification methods are mechanical, chemical, sol-gel, oxidation, carburization and ion implantation. The last three methods will be discussed in detailed in later sections. Mechanical surface treatments include machining, grinding, and blasting. These methods were discussed in depth elsewhere (Lausmaa et al., 2001). The main goal of mechanical modification is to obtain particular surface roughness and topographies on implant surface. In general, mechanical surface treatments lead to rough structures which finally increase the surface area of implant. This condition is considered more favourable for the implant because it facilitates biomineralization process to take place (Sobieszczyk, 2010a). Surface roughness enhances cell attachment, proliferation and differentiation of osteogenic cells and is the key factor for the osseous integration of metallic implants. Among the mechanical methods, blasting is the most popular technique for achieving desired surface roughness on titanium. The common abrasive particles used as the blasting media are silicon carbide $(\mathrm{SiC})$, alumina $\left(\mathrm{Al}_{2} \mathrm{O}_{3}\right)$, biphasic calcium phosphates (BCP), hydroxyapatite and $\$$-Tricalcium phosphate (Citeau et al., 2005). One of the disadvantages of blasting is that it may lead to surface contamination and local inflammatory reactions of surrounding tissues as a result of dissolution of abrasive particles 
into the host bone (Gbureck et al., 2003). A range of surface roughness ( $\mathrm{Ra}=0.5-1.5 \mu \mathrm{m})$ shows stronger bone response after the implantation compared to implants with smoother or rougher surface (Sobieszczyk, 2010b). This observation was in contrast with the findings by Fini et al. (2003), that rougher surface show encouraging results. Their results were confirmed in the vivo experiments using titanium implants having roughness of $16.5-21.4$ $\mu \mathrm{m}$ inserted in the cortical and trabecular bone of goats.

Chemical methods include acid treatment, alkali treatment, sol-gel, oxidation, chemical vapour deposition (CVD), and biochemical modification. Following discussion is limited to the first four chemical methods. Since oxidation method itself is a big field, this technique is separately discussed in section 4 .

Acid treatment is a popular surface treatment method to clean substrate surface by means of removing oxide and contamination. A mixed acids solution is frequently used for this purpose (Nanci et al., 1998). It is also noted that $\mathrm{TiO}_{2}$ is the dominant oxide layers formed on the substrate due to high affinity of titanium to react with $\mathrm{O}_{2}$. These oxides need to be removed prior to other surface treatments such as HA coating, thermal oxidation or carburization and ion implantation. A recommended standard solution for acid treatment is composed of $\mathrm{HNO}_{3}$ and $\mathrm{HF}$ (ratio of 10 to 1 by volume) in distilled water. Hydrofluoric acid has natural tendency of quickly attack $\mathrm{TiO}_{2}$ in the acid solution and forms soluble titanium fluorides and hydrogen. This acid solution also can be used to minimize the formation of free hydrogen that prevent surface embrittlement occurs due to inclusion of hydrogen in titanium (American Society for Testing and Materials, 1997). A group of researchers investigated the decontamination efficiency to the Ti surface using three acids, $\mathrm{Na}_{2} \mathrm{~S}_{2} \mathrm{O}_{8}$, $\mathrm{H}_{2} \mathrm{SO}_{4}$, and $\mathrm{HCl}$ (Takeuchi et al., 2003). They found that $\mathrm{HCl}$ was the most effective decontamination agent among these three due to the capability to dissolve titanium salts easily without weakening Ti surfaces.

Alkali treatment can be simply defined as simple surface modification by alkali solution such as $\mathrm{NaOH}$ or $\mathrm{KOH}$ to form bioactive porous layer on substrate materials. Later, this method followed by thermal treatment to dehydrate and transform amorphous structure into porous crystalline. The combined treatment is called Alkali Heat Treatment (AHT). The alkali treatment process is started by immersing titanium alloy in a 5-10 M NaOH or $\mathrm{KOH}$ solution for $24 \mathrm{hr}$ (Kim et al., 1996). After that specimens have to rinse with distilled water followed by ultrasonic cleaning. It is then dried in an oven. Finally heat treatment is carried out by heating the specimens around $600-800 \circ \mathrm{C}$ for $1 \mathrm{hr}$. The heat treatment is performed at very low pressure for avoiding oxidation of titanium at high temperature. The porous surface formed on treated titanium surface disclosed the formation of sodium titanate hydrogel on the titanium substrate. It was observed that after thermal treatment, a large quantity of crystalline sodium titanate with rutile and anatase precipitated. Bioactive bonelike apatite was obtained on the surface after soaking the treated titanium in simulated body fluid (SBF) for 4 weeks. They found that bone-like apatite layer which is bioactive can be formed on other surfaces such as bioglass, hydroxyapatite and glass-ceramic by using this method. It is noted that bioglass, hydroxyapatite and glass-ceramic all are the examples of bioactive ceramics. Recently, a group of researchers investigated the effect of substrate surface roughness on alkali treated CP-Ti for apatite formation after immerging in SBF solution for seven days (Ravelingien et al., 2010). They found that apatite formation increased with the moderate surface roughness. However, very smooth surface $(<0.5 \mu \mathrm{m})$ causes sudden decrease in apatite formation. 
Sol-gel consists of two terms, sol and gel. A sol can be defined as a colloidial suspension of very small solid particles in a continuous liquid. Gel can be defined as a substance that contains a continuous solid skeleton enveloping a continuous liquid phase (Brinker, 1990). The sol-gel process consists of five main steps: (1) hydrolysis and polycondensation; (2) gelation; (3) aging; (4) drying; (5) densification and crystallization (Piveteau et al., 2001). Two different techniques usually used to carry out the sol-gel process: (i) spin coating technique and (ii) dip coating technique. In spin coating technique the specimens are spun to spread the coating solution on the substrate using centrifugal force where in dip coating specimens are dipped or submerged in the solution. The sol-gel process is popular for depositing thin $(<10 \mu \mathrm{m})$ ceramic coatings (Liu et al., 2004). In the biomedical area, the sol-gel process is considered new field. Sol-gel method capable of producing various types of coatings on titanium and titanium alloys for biomedical applications. Examples of these coatings are titanium oxide $\left(\mathrm{TiO}_{2}\right)$, calcium phosphate $(\mathrm{CaP})$, and $\mathrm{TiO}_{2}-\mathrm{CaP}$ composite. Sol-gel technique also has been applied for some silica-based coatings. It has a great potential to replace plasma spray for synthesizing the composite hydroxyapatite/titania coating on the titanium substrate with high adhesion and good bioactivity (Kim et al., 2004). It is reported that plasma spray method results in chemical inhomogeneity and low crystallinity of HA coating on titanium alloys (Wang et al., 2011). In contrast, sol-gel technique produces high crystalline HA microstructure and better chemical homogeneity due to ability to mix the calcium and phosphorus precursors at molecular-level. They also found that atomic diffusion accelerated when increasing the calcining temperature or prolong the calcining time. Other advantages of sol-gel method in comparison with other conventional thin layer oxidation processes are: i) low densification temperature, ii) better control of the homogeneity, chemical composition and crystalline structure of the thin coating, iii) Cost effective and less complicated equipment.

\section{Oxidation}

Oxidation is a chemical reaction between metal and oxygen. This reaction occurs naturally. However, this reaction can be started with exciting the atoms by providing external energy. In simple way, an oxidation is defined as a chemical reaction by the interaction of metal with oxygen to form an oxide. The oxidation behaviour of a metal depends on various factors and the reaction mechanism usually quite complex. The phenomena started with adsorption of oxygen molecules from the atmosphere, and then followed by nucleation of oxides, formation of a thin oxide layer, finally growth to a thicker scale. During the growth process, nodule formation and scale spallation may also take place (Khanna, 2004) . The total chemical reaction for the formation of oxide $\left(\mathrm{M}_{\mathrm{a}} \mathrm{O}_{\mathrm{b}}\right)$ by oxidation between metal $(\mathrm{M})$ and oxygen gas $\left(\mathrm{O}_{2}\right)$ the can be written as:

$$
\mathrm{aM}+(\mathrm{b} / 2) \mathrm{O}_{2}=\mathrm{M}_{\mathrm{a}} \mathrm{O}_{\mathrm{b}}
$$

The mechanism of oxidation process is illustrated in Fig. 2. The initial step started by the adsorption of gas on the clean metal surface during the metal-oxygen reaction. As the reaction proceeds, oxygen may dissolve in the metal forming an oxide on the surface either as a film or as oxide nuclei. The gas adsorption and initial oxide formation both are functions of various factors: (i) surface orientation, (ii) crystal defects at the surface, (iii) surface preparation, and (iv) impurities in both the metal and the gas. The oxides formed on 
surface separates the metal and the gas and sometimes act as a barrier for further oxide formation. This barrier oxide is called protective oxide layer. The oxide can be continuous film or porous structure. Oxides can also be liquid or volatile at high temperature. In general, the reaction mechanism for a specific metal will be a function of several factors: (i) pre-treatment and surface preparation of the metal, (ii) temperature, (iii) gas composition, (iv) pressure and (v) required time of reaction (Kofstad, 1988). The oxidation mechanism can be generalised both at room temperature as well as at high temperature. The basic difference between oxidation at room temperature and high temperature is the reaction rate. At room temperature reaction rate is very slow where at high temperature the rate is accelerated. There are various types of oxidation for surface modification of biomedical grade titanium alloy such as (i) Thermal oxidation, (ii) Anodic oxidation, (iii) Micro-arc oxidation (MAO). These techniques are discussed separately in 4.2, 4.3 and 4.4 respectively.
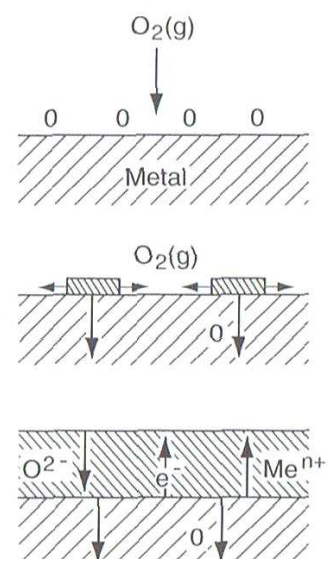

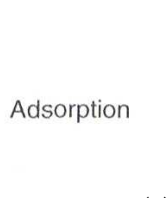

Oxide nucleation + growth Oxygen dissolution

(b)

Film/scale growth Internal oxidation

(c)

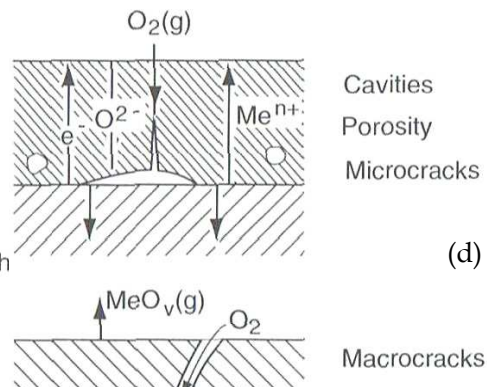

Possible molten oxide phases, oxide evaporation

(e)

Fig. 2. Scale Formation during high temperature metal oxidation: (a) $\mathrm{O}_{2}$ gas absorption, (b) $\mathrm{O}_{2}$ dissolution, (c) Thin oxide film formation, (d) Oxide layer growth, (e) Thick oxide layer (Kofstad, 1988)

\subsection{Mechanism of oxidation based on thermodynamic point of view}

In oxidation, the chemical reaction between a metal $(\mathrm{M})$ and the oxygen gas $\left(\mathrm{O}_{2}\right)$ can be written as:

$$
\mathrm{M}(\mathrm{s})+\mathrm{O}_{2}(\mathrm{~g})=\mathrm{MO}_{2}(\mathrm{~s})
$$

In thermodynamic point of view, if oxygen potential in the environment is greater than the oxygen partial pressure in equilibrium with the oxide then an oxide will form on the surface of that metal. This equilibrium oxygen pressure is determined from the standard free energy of formation of the oxide. This equilibrium oxygen pressure is also called the dissociation pressure of the oxide in equilibrium with the metal. From equation 2, the standard free energy of the oxidation can be written as,

$$
\Delta \mathrm{G}^{\mathrm{o}}=-\mathrm{RT} \ln \left(\mathrm{a}_{\mathrm{MO} 2} / \mathrm{a}_{\mathrm{M}} \cdot \mathrm{P}_{(\mathrm{O} 2)}\right)
$$


Where,

$\Delta \mathrm{G}^{\mathrm{o}}=$ Gibbs free energy

$\mathrm{R}=$ Universal gas constant

$\mathrm{T}=$ Absolute temperature

$\mathrm{a}_{\mathrm{MO} 2}$ and $\mathrm{a}_{\mathrm{M}}=$ Activities of the oxide and the metal respectiely

and $a_{M}$ (element activity in alloy) $=\gamma_{M} . X_{M}$;

$\gamma_{M}=$ the activity coefficient of metal in the alloy ;

$\mathrm{X}_{\mathrm{M}}=$ mole fraction of metal in the alloy;

$\mathrm{P}_{(\mathrm{O} 2)}=$ Partial pressure of the oxygen gas.

If a value coefficient $\gamma_{M}$ is not available, ideal behaviour is assumed and $\gamma_{M}$ is assigned the value of unity. Assuming element activity of the solid constituents is unit, i.e. the metal and oxide, the equation 3 becomes

$$
\begin{aligned}
\Delta \mathrm{G}^{\mathrm{o}} & =-\mathrm{RT} \ln \mathrm{P}_{(\mathrm{O} 2)} \\
\text { Or, } \quad \mathrm{P}\left(\mathrm{O}_{2}\right) & =\exp \left(\Delta \mathrm{G}^{\mathrm{o}} / \mathrm{RT}\right)
\end{aligned}
$$

Therefore, equation 5 can be used to determine the partial pressure of oxygen required for any metal to form oxide at any temperature from the standard free formation energy. Standard free energy for the formation of oxides is a function of temperature. This can be obtained from the Ellingham/Richardson diagrams which is mentioned elsewhere (Khanna, 2004).

\subsection{Thermal oxidation}

Thermal oxidation occurs when metals or alloys are heated in a highly oxidizing atmosphere such as air or in the presence of oxygen. It is one of the cost- effective surface modification methods to deliberately generate a barrier oxide layer on titanium alloy. Thermal oxidation treatment aims for obtaining a ceramic coating, mainly focussed on rutile structure. Particularly, oxidation at temperature above $200{ }^{\circ} \mathrm{C}$ promotes the development of a crystalline oxide film. Many researchers reported that the thermally formed oxide layer enables increment in hardness, wear resistance and corrosion resistance of titanium and its alloy (Borgioli et al., 2005, Kumar et al., 2009). This protective oxide layer also reduce ion release inside body fluid and thus helps the body from metal toxicity (López et al., 2010). During thermal oxidation process, titanium can easily reacts with air due to its affinity to oxygen. Three types of oxides structure can be produced through this method, which are rutile, brookite or anatase structures. Among the three, rutile structure is more preferable for several reasons. Rutile structure is more inert to bacterial attack (Bloyce et al., 1998), has high hardness and low friction coefficient that can reduce wear as compared to the other two structures (Krishna et al., 2005).

Many researchers investigate thermal oxidation method to solve ion release issues through increasing the corrosion resistance of titanium alloy. A group of researchers studied the chemical composition of oxide layer produced by thermal oxidation on vanadium free $\mathrm{TiNb}$ and TiZr based alloys (López et al., 2001). Their aim was to reduce ion release as well as improving corrosion resistance for better biocompatibility. They reported that $\mathrm{Ti}, \mathrm{Al}$ and $\mathrm{Zr}$ based oxide dominate the surface where small amount of $\mathrm{Nb}$ based oxide formed. They also 
explored further to study the chemical composition of the deeper oxide layer surface and found that rutile structure dominates in oxide layer of TiZr based alloy (López et al., 2002). Another group of workers investigated the oxide structure to develop thicker oxide layer for improving the corrosion resistance as well as biocompatibility (Morant et al., 2003). They found that oxide layer was compact and uniform with the granular structure in $\mathrm{TiNb}$ based alloy and longitudinal groove structure in TiZr based alloy. It was investigated the corrosion- wear responses by increasing hardness through thermal oxidation of CP-Ti and Ti-6Al-4V (Dearnley et al., 2004). They found that corrosion-wear resistance improved by oxidation where surface of oxidized Ti-6Al-4V is harder than CP-Ti.

Some investigators study the effect of oxidation time on surface roughness of oxide layer through this method to improve surface structure for better corrosion resistance (Gutiérrez et al., 2006). It is noted that higher surface roughness will provide better cell adhesion. They observed that surface roughness increases with the increase of oxidation time. A group of researchers investigated in depth chemical composition of oxide layer to understand the diffusion of elements in the substrate during oxidation (Gutiérrez et al., 2008). Their motivation was to produce thick oxide layer for reducing ion release as well as corrosion protection. They observed that TiZr based alloy showed thicker oxide layer than TiNb based alloy but less homogenous. Another group of researchers studied extensively to optimize the oxidation temperature and time (Kumar et al., 2010b). Their objectives were to produce well adherence oxide layer with rutile structure for improving corrosion resistance and biocompatibility. They observed that best corrosion resistance achieved by oxidation at 650 ${ }^{\circ} \mathrm{C}$ for $24 \mathrm{hr}$ and the hardness increased threefold at $650{ }^{\circ} \mathrm{C}$ for $48 \mathrm{hr}$ compare to bare metal.

Excessive wear rate is another issue that limit the usage of titanium alloy in various articulation applications. To address the wear resistance issue, another group of researchers investigated the effect of oxidation and temperature on hardness of the oxide layer formed through thermal oxidation on CP-Ti (Yan et al., 2004). They found that thickness of the oxide layer increases with increasing temperature or time and hardness also increases accordingly. Another team of researchers studied the effect of temperature on adhesion and hardness of the oxide layer through thermal oxidation (Rastkar et al., 2005). Their aim was to improve sliding wear resistance by providing hard surface on TiAl based alloy. They observed that higher temperature oxide layer is non-adherent where lower temperature produced adherent oxide layer and also hardness increases with the oxidation temperature increment. Other group of workers also investigated the effect of oxidation time on oxide layer produced through this method (Guleryuz et al., 2005). They wanted to evaluate the dry sliding wear performance on Ti-6Al-4V by providing hard surface. They observed that hardness and surface roughness increases with the increase of oxidation time and these hard oxide layers show significant improvement in dry sliding wear resistance. Another team of researchers investigated the effect of oxidation time and temperature to developed well adherent rutile based oxide surface in order to improve wear resistance (Biswas et al., 2009). It is also noted that rutile structure provides higher hardness compared to anatase structure. They observed that hardness is proportional to oxidation time as well as temperature. However, higher temperature shows significant increase of hardness compared to higher oxidation time.

An appropriate articulating implant should possess the modulus of elasticity close to the bone. Otherwise, this could lead to stress shielding effect which is a loss of bone density. A 
team of researchers made an effort to address the stress shielding issue of $\mathrm{TiNb}$ and TiZr based implant alloys (Munuera et al., 2007). They studied the surface structural properties by evaluating the nanoscale elastic properties of oxide layers at various oxidation times. They found that most cases the Young moduli of the oxide layer are lower than 65 GPA and in some cases it is almost near to bone i.e. 20 GPA. In other study, the nanomechanical properties of oxide scale (hardness and Young modulus) was also investigated (Cáceres et al., 2008). They noticed that TiZr based alloy shows increment in hardness and Young modulus after thermal oxidation. However, TiNb shows reduction in hardness and Young modulus at prolonged oxidation duration which is near to bone. Several researchers also investigated the effective oxidation parameters to produce rutile structure through thermal oxidation. As mentioned earlier, rutile structure is more preferable compared to other structures due to better resistant to bacterial attack and also having higher hardness. A group of researchers carried out thermal oxidation process on Ti-6Al-7Nb, Ti-13Nb-13Z $\mathrm{Zr}$, and $\mathrm{Ti}-15 \mathrm{Zr}-4 \mathrm{Nb}$ at $750{ }^{\circ} \mathrm{C}$ for 24 hours (López et al., 2003). They reported that TiNbZr based alloys present a thicker scale with rutile structure. Other group of researchers studied the effect of producing rutile structure on AISI 316L coated with titanium (Krishna et al., 2005). They found that the presence of rutile structure improves the hardness and corrosion resistance. Another group of workers investigated the effect of thermal oxidation temperature on the Commercial Pure Titanium (CP-Ti) (Kumar et al., 2010a). They reported that rutile structure can be obtained at $800{ }^{\circ} \mathrm{C}$ after continuous heating for 24 hours. Another group of researchers carried out experiments to investigate the effects of different pickling times as well as temperature on the adhesion strength of oxide layer formed on the Ti-6Al$4 \mathrm{~V}$ after oxidation process (S. Izman et al., 2011a). It was revealed that the thickness of oxide layer increases with pickling time but the adhesion strengths become lower. It was also found that the adhesion strength of oxide layer formed on Ti substrate surface increases with the increase of temperature while the thickness of the oxide layer decreased within 40 ${ }^{\circ} \mathrm{C}$ pickling temperature. Izman et al took an attempt to evaluate the effect of thermal oxidation temperature on surface morphology and structure of the Ti13Nb13Zr biomedical material (S. Izman et al., 2011c). It is noted that all thermally oxidized samples exhibit the presence of oxides without spallation regardless of the thermal oxidation temperatures. Surface morphology of oxidized substrates changes from smooth to nodular particles-like shape when the oxidation temperature increases from low to high. Rutile structure dominants the surface area when the substrate is thermally oxidized at $850{ }^{\circ} \mathrm{C}$. In summary, thermal oxidation is a simple and low cost method to produce protective oxide layer with rutile structure on titanium alloys. Studies show that the Young modulus of rutile structure is near to that of the bone (less than $65 \mathrm{GPa}$ ) and has antibacterial effect, better corrosion and wear resistance. Despite these encouraging properties, limited works have been reported on the adhesion strength of oxide layer formed on the titanium substrate.

\subsection{Anodic oxidation}

Anodic oxidation is an electrochemical reaction which is a combined phenomenon of diffusion between oxygen and metal ion. In this technique, the metal ion is driven by an electric field. This phenomenon leads to oxide layer formation on the surface of anode (Liu et al., 2004). Anodic oxidation can be used for producing different types of protective oxide layer on different metals. Common electrolytes used in the process are various diluted acids such as $\mathrm{H}_{2} \mathrm{SO}_{4}, \mathrm{H}_{3} \mathrm{PO}_{4}$, acetic acid, etc. The main advantage of anodic oxidation compared to 
other oxidation methods is their ability to form bioactive oxide film on surface of titanium and its alloy. Anodic oxidation increases thickness of the oxide layer for reducing ion release as well as improving corrosion protection. By varying the anodic oxidation parameters, such as current, process temperature, electrolyte composition, and anode potential, the oxide film properties i.e. chemical or structural can be changed.

Principal reactions cause oxidations at the anode are as follows:

At the Ti/Ti oxide interfaces:

$\mathrm{Ti} \leftrightarrow \mathrm{Ti}^{2+}+2 \mathrm{e}^{-}$

At the Ti oxide/electrolyte interfaces:

$2 \mathrm{H}_{2} \mathrm{O} \leftrightarrow 2 \mathrm{O}^{2-}+4 \mathrm{H}^{+}$(oxygen ions react with Ti to form oxide) ,

$2 \mathrm{H}_{2} \mathrm{O} \leftrightarrow \mathrm{O}_{2}$ (gas) $+4 \mathrm{H}^{+}+4 \mathrm{e}^{-}\left(\mathrm{O}_{2}\right.$ gas evolves or stick at anode surface).

At both interfaces:

$\mathrm{Ti}^{2+}+2 \mathrm{O}^{2-} \leftrightarrow \mathrm{TiO}_{2}+2 \mathrm{e}^{-}$

In anodic oxidation, a linear correlation exists between the oxide film thickness and applied voltage. If the final oxide thickness is $\mathrm{d}$ and the applied voltage is $\mathrm{U}$, then the relationship is $\mathrm{d}=\mathrm{aU}$. $\mathrm{a}$ is a constant and its typical range is $1.5-3 \mathrm{nmV}^{-1}$. Ishizawa and Ogino et al. is the pioneer in developing $\mathrm{Ca}$ and $\mathrm{P}$ contained oxide layer through anodizing titanium in $\beta$ glycerophosphate sodium and calcium acetate contained electrolyte (Ishizawa and Ogino, 1995). They further proceeded exploring and able to transform it into hydroxyapatite by applying hydrothermal treatment. The results showed that the electrolyte possessed some impurities (e.g. sodium). These impurities decreased oxide layer's strength. A group of researchers reported that desirable cellular behaviour such as cell growth, cell attachment, etc. can be obtained from the thin HA layer on the surface of $\mathrm{CP}-\mathrm{Ti}$ which was produced by anodization and subsequently followed by hydrothermal treatment (Takebe et al., 2000). It is observed that cellular attachment and spreading are affected by this thin HA layer on the $\mathrm{CP}-\mathrm{Ti}$ surface. It is also revealed a thin HA layer on titanium surface shows more osteoconductive behaviour to cell attachment as compared to bare CP-Ti. Other group of workers investigated new electrolytes consists of calcium glycerophosphate and calcium acetate for producing anodic oxide films that consist of $\mathrm{Ca}$ and $\mathrm{P}$ on titanium implants (Zhu et al., 2001). The anodic oxide film of titanium obtained using this method is highly crystalline with porous structure and rich in $\mathrm{Ca}$ and $\mathrm{P}$. The recommended optimum conditions are: (i) $350 \mathrm{~V}$ as final voltage, (ii) $70 \mathrm{~A} \mathrm{~m}^{-2}$ as current density, and (iii) concentrations of the calcium glycerophosphate $(0.02 \mathrm{M})$ and calcium acetate $(0.15 \mathrm{M})$. Ca and $P$ ratio near to 1.67 was achieved using this recommended condition. Positive biological response also observed from the properties of that anodic oxide layer surface. Yang et al. reported that using anodic oxidation in $\mathrm{H}_{2} \mathrm{SO}_{4}$ solution united with consequent heat treatment is an efficient method for obtaining titanium alloy with bioactive surface (Yang et al., 2004). They also observed that the porous structure Titania of anatase and/or rutile phase covered on the surface after anodic oxidation. It was interesting to observe that apatite can be formed on titanium alloy by anodic oxidation in simulated body fluid. The initial time for apatite formation was inversely proportional to the quantity of rutile or anatase phase (Liu et al., 2004). Apatite cannot be formed without spark discharge on the surface although anatase was produced on anodically oxidized titanium. Hence, a combination of anodic oxidation with heat treatment is required for the apatite formation on titanium in SBF without spark discharge treatment. Heat treatment induces apatite formation in SBF since the amount of anatase and/or rutile increases by the heat treatment. 
This also indicates that prior to the formation of apatite on the surfaces, a titanium oxide with three-dimensional micro-porous structure may be essential. It is also noted that surfaces can be bioactive by containing $\mathrm{Ca}$ and/or $\mathrm{P}$ which leads to osteoinduction of new bones. Wojciech (2011) investigated the effective anodic voltage for producing better corrosion resistance bioactive oxide layer containing $\mathrm{Ca}$ and $\mathrm{P}$ on TiZr based alloy through anodic oxidation method. He found that lower anodic voltage produced highest corrosion resistance. However, higher anodic voltage provides bioactive oxide layer rich in $\mathrm{Ca}$ and $\mathrm{P}$ on TiZr based alloy which also increase the corrosion resistance. In summary, anodic oxidation is a simple and effective method of surface modification for providing better bioactive surface of titanium alloys which also homogenous and highly crystalline. However, bioactive apatite formation on titanium alloy through this method required posttreatment such as hydrothermal heat treatment. The oxide film produced by anodic oxidation method shows various properties such as better biocompatibility, corrosion resistance, osteoconductive, etc. These properties rely on the microstructure and composition of the materials as well as anodic oxidation parameters, such as current, temperature, anode potential and electrolyte composition.

\subsection{Micro-arc oxidation (MAO)}

Another name of micro-arc oxidation is anodic spark oxidation or plasma electrolytic oxidation (PEO). Micro arc oxidation is an electrochemical surface modification process for producing oxide coatings on metals such as $\mathrm{Al}, \mathrm{Ti}, \mathrm{Mg}, \mathrm{Ta}, \mathrm{W}, \mathrm{Zn}$, and $\mathrm{Zr}$ and their alloys (Liu et al., 2010). According to Yerokhin et al. (1999), MAO can be defined as a complex plasma-enhanced physico-chemical process which involved micro-arc discharge, diffusion and plasma chemical reactions. Basically, it is a new type of anodic oxidation technique, but the difference between MAO and the conventional anodic oxidation is it employs higher potentials to discharges and the resulting plasma modifies the structure of oxide layer. This process can be used to grow crystalline oxide coating with thickness range from ten to hundreds $\mu \mathrm{m}$. The coating thickness depends on process parameters such as current density, process time, electrolyte temperature, applied voltage, electrolyte composition, alloy composition (Dunleavy et al., 2009). A large number of short-lived sparks (micro arc discharges) produced in MAO process is a result of localized electrical breakdown of the growing coating. These discharges play the key role in the coating growth mechanism as they deposit 'craters' on the free surface of the growing coating. In MAO process, the anode is immersed in electrolyte which is an aqueous solution. The anode is made from valve metals. Valve metals usually refer to $\mathrm{Ti}, \mathrm{Al}, \mathrm{Mg}, \mathrm{Ta}, \mathrm{W}, \mathrm{Zn}$, and $\mathrm{Zr}$ due to their usage as a cathode to emit electron in electronic valve. They are also known as 'thermionic valve' materials in early days. However, disputes on the right definition of these terms have been remained among researchers since $\mathrm{Al}$ is not a suitable material for high temperature resistance to emit electron. In $\mathrm{MAO}$, an unequal alternating voltage between the anode and cathode initiates an electrical discharge at the anode. The typical voltage range for anode and cathode is from 150 to $1000 \mathrm{~V}$ and from 0 to $100 \mathrm{~V}$ respectively. Temperature and local pressure in the discharge channels are among the parameters that affect the MAO coating qualities such as high strength, well adhesion, high micro-hardness, and wear resistance (Liu et al., 2010). Since MAO can provide high hardness and a continuous barrier, this coating is suitable for protection against wear, corrosion or heat as well as electrical insulation (Curran and Clyne, 2005). General characteristics of these coatings are porous, 
firm adhesion to substrates and the pores are homogenously distributed on the coating's surface with nanostructure grains (Kim et al., 2002). Due to superior corrosion resistance, thermal stability, photocatalytic activity, wear resistance and CO sensing properties makes MAO coatings as a popular research area (Shin et al., 2006, Jin et al., 2008). MAO has been popular in the biomedical community since Ishizawa et al. pioneered the technique to biomedical titanium implants (Ishizawa and Ogino, 1995). Biomimetic deposition of apatite is possible on Ca and P-containing MAO coatings (Song et al., 2004). Zhao et al. found that the MAO coatings benefit osteoblast adhesion (Zhao et al., 2007). They compared the adhesion performance of MAO coatings on various modified smooth and rough surfaces. Other researchers investigated the effect of variations in the electrolyte compositions to produce different kinds of nanostructured composite coatings under this method (Kim et al., 2007, Yao et al., 2008). Cimenoglu et al. investigated the MAO coating on Ti6Al7Nb and found that oxide layer shows grainy appearance rather than porous and contained calcium titanate precipitates, HA and rutile structure (Cimenoglu et al., 2011). In summary, MAO is a potential method for producing porous nanostructured coatings on $\mathrm{Ti}$ and its alloys which promote best osteoblast cell adhesion. This technique has been spreading into the field of orthopaedic and dental implant materials.

\section{Carburization of titanium alloy}

Poor tribological properties limit the usefulness of titanium alloy in many engineering applications (Bloyce et al., 1994). Moreover, not all titanium and its alloys can meet all of the clinical requirements. In order to improve the biological, chemical, and mechanical properties, surface modification is often performed (Huang et al., 2006, Kumar et al., 2010b). Till now various surface modification techniques by thermo-chemical process have been studied and applied for improving wear resistance of titanium alloys. These are carburizing, nitriding and oxidation (Biswas et al., 2009, Tsuji et al., 2009b, Savaloni et al., 2010). Among them, carburization technique is one of the methods that can be used to form hard ceramic coating on titanium alloys. The main objective of carburization is to provide hard surface on titanium and its alloys for increasing wear resistance in articulation application since titanium carbide is one of the potential biocompatible carbide layers (Bharathy et al., 2010). It is also one of the cost-effective surface modification methods to deliberately generate a carbide layer on titanium alloy. Many researchers reported that the carbide layer enables to increase hardness, wear resistance and corrosion resistance to titanium and its alloy (Kim et al., 2003). Sintered solid titanium carbide is a very important non-oxide ceramics that widely used in the fields of wear resistance tools and materials due to its high melting point $(3170 \circ \mathrm{C})$, low density, high hardness $(2500 \sim 3000 \mathrm{HV})$, superior chemical and thermal stability, and outstanding wear resistance (Courant et al., 2005). Apart from sintering, titanium carbide layer can be created by other surface modification methods, such as plasma carburizing process, thermal carburization or high-temperature synthesis, carburization by laser melting, gas-solid reaction or gas carburization and sol-gel process (Lee, 1997, Yin et al., 2005, Cochepin et al., 2007, Luo et al., 2011). Among these methods, thermal carburization process is considered as the simplest and the most cost effective. Typically, one of the main obstacles for $\mathrm{TiC}$ coating is the high affinity of titanium to oxygen which leads to form $\mathrm{TiO}_{2}$ easily on the surface. To overcome this issue, vacuum carburization or inert gas environment is introduced to remove $\mathrm{O}_{2}$ contents in carburization chamber (Wu et al., 1997). Another common problem related to carburization is non uniform hardness profile across 
the carburized layers due to variation of carbon concentration in the surface region (Saleh et al., 2010). The discussion of this chapter starts with the basic mechanism of carburization followed by three popular carburization methods, i.e. thermal, gas and laser melting.

\subsection{Basic mechanism of carburization}

Carburization is a process widely used method to harden the surface and enhance the properties of components that made from metal. Carburizing consists of absorption and diffusion of carbon into solid metal alloys by heating at high temperature. Historically, the carburizing process is generally done at elevated temperatures with a carbon medium that can supply adequate quantity of atomic carbon for absorption and diffusion into the steel (Luo et al., 2009). The carbon medium that use for carburizing process can be solid (charcoal), molten salt (cyanide), a gaseous or plasma medium (Prabhudev, 1998). There are three methods of carburizing process, i.e. solid carburizing, liquid carburizing, and gas carburizing. All these three methods have their own compounds medium that is used for the carbon supply during the process. In solid carburizing process, carburizing compound such as charcoal or graphite powder is used for its medium. In the liquid carburizing method, molten cyanide is used for carbon enrichment. Lastly, for the gas carburizing method, hydrocarbon gas or plasma is used as the source of the carburizing medium.

During carburizing, the atomic carbon is liberated from carbonaceous medium due to decomposition of carbon monoxide into carbon dioxide and atomic carbon as given below:

$$
2 \mathrm{CO} \rightarrow \mathrm{CO}_{2}+\mathrm{C}_{\mathrm{at}}
$$

Then, the carbon atom from carburizing medium is transferred to the surface of the metal. These metal surfaces will absorb the carbon and diffuse deep into it. Thus, this phenomena results increase in hardness of the substrate materials surface.

\subsection{Thermal carburization}

Thermal carburization process is considered the earliest carburization technique and it is a kind of solid carburization. Generally solid particle such as charcoal, graphite powder, etc is used as a carbon source to surround titanium substrate during carburization process. Titanium can easily react with oxygen in ambient environment and form a thin passive layer of $\mathrm{TiO}_{2}$ on the outer surface with thickness range of 3 to $7 \mathrm{~nm}$ (Liu et al., 2004). This passive layer becomes a barrier for carbon atom diffusion into the titanium surface. Since titanium is highly affinity to oxygen, an inert or vacuum environment is preferable for conducting carburization process. Argon gas is commonly used as a medium to remove oxygen in tube or muffle furnace heating chamber from pre-oxidizing the titanium substrate surface. The quality of carburized layer largely depends on the carburizing temperature, soaking time, source of carbon (type and particle size) and the absence of oxygen level in the chamber. The carburizing parameters may have significant effects on the thickness, adhesion, density and chemical composition of carburized layer formed on the titanium substrate. Studies on titanium carbide powder synthesis by carbothermal method in argon environment requires high temperature in the range of $1700-2100{ }^{\circ} \mathrm{C}$ (Weimer, 1997) and long reaction time (10-24 h) (Gotoh et al., 2001). Other workers tried to synthesize $\mathrm{TiC}$ powder at lower temperatures and shorter time with success. For instance, Lee et al. studied the chemical kinetics at various 
temperatures $\left(1100\right.$ to $\left.1400{ }^{\circ} \mathrm{C}\right)$ for synthesising TiC from CP-Ti alloy and graphite powders (Lee and Thadhani, 1997). They found that Ti with compacted graphite powder shows highly activated state of reactants which reduce activation energies by 4-6 times, undergo a solid state diffusion reaction. They also concluded that increasing temperature will increase the rate of heat released. This released heat generates localized melting of unreacted Ti and initiate a combustion reaction. It has been reported that the carburizing rate of titanium dioxide, $\mathrm{TiO}_{2}$ into $\mathrm{TiC}$ can be accelerated by using the finest and homogenous carbon powder (Maitre et al., 2000). Sen et al produced fine and homogeneous TiC powders by carbothermal reduction of titania/charcoal in a vacuum furnace at different reaction temperatures from $1100{ }^{\circ} \mathrm{C}$ to $1550{ }^{\circ} \mathrm{C}$ (Sen et al., 2010). They observed that reaction temperature increases, uniform crystal grain arises with the liberation of much $\mathrm{CO}$ and higher temperature (at $1550{ }^{\circ} \mathrm{C}$ ) produced large amount of TiC. They also noticed that as reaction temperature increased, formation of the compounds was in sequenced as $\mathrm{Ti}_{4} \mathrm{O}_{7}$, $\mathrm{Ti}_{3} \mathrm{O}_{5}, \mathrm{Ti}_{2} \mathrm{O}_{3}, \mathrm{TiC}_{\mathrm{x}} \mathrm{O}_{1-\mathrm{x}}$ and $\mathrm{TiC}$. Hardly found researchers study $\mathrm{TiC}$ formation on titanium solid substrate. Izman et al initiated the study to investigate the effects of different carburizing times on the adhesion strength of carbide layer formed on the Ti-6Al-7Nb (S. Izman et al., 2011b). Prior to carburization process, all samples were treated to remove residual stress and oxide scales by annealing and pickling processes respectively. Hard wood charcoal powder was used as a medium. The carburizing process was carried out under normal atmospheric condition. They found that a mixture of oxide and carbide layers formed on the substrate and the thickness of these layers increases with carburizing time. It was also revealed that the longer carburizing time provides the strongest adhesion strength and $\mathrm{TiC}$ as the dominant layer. Porous structure of $\mathrm{TiC}$ was observed and this structure is believed able to facilitate the osteoblast cell growth on implant. In summary, thermal carburization is a simple and cost effective method to produced $\mathrm{TiC}$ for increasing the wear resistance properties of titanium and its alloys. However, the technique has not been explored rigorously this far. Issues regarding carbide grain growth, carbon particle agglomeration, non-uniform carbide particle shapes and large amounts of unreacted $\mathrm{TiO}_{2}$ and carbon in the substrate are still under on-going research.

\subsection{Gas carburization}

The main difference between thermal and gas carburization process is the carbon source medium. Instead of solid, hydrocarbon gas is used as a carbon source and carburization process takes place either under gaseous or plasma condition. This process is typically performed using plasma or flowing hydrocarbon gas over the $\mathrm{Ti}$ and $\mathrm{Ti}$ alloy substrate at high temperature in a inert gas or vacuum furnace. Gas carburizing also have various categories such as hydrocarbon gas carburizing (using methane or ethane), plasma carburizing, etc. The advantage of gas carburizing over solid carburising is faster processing time but this method is costlier compared to solid carburization (Robert et al., 1994). Due to high affinity to oxygen, plasma carburizing method has difficulties in carburizing the $\mathrm{Ti}$ alloys because thin protective titanium oxide film easily forms on its surface which cause in obstruction of the carbon diffusion (Okamoto et al., 2001). Kim et al carburized Ti6Al4V at $900{ }^{\circ} \mathrm{C}$ and $250 \mathrm{MPa}$ pressure using $\mathrm{CH}_{4}-\mathrm{Ar}-\mathrm{H}_{2}$ plasma for $6 \mathrm{hrs}$ to increase the wear resistance (Kim et al., 2003). Hardness of titanium alloy was improved significantly from $400 \mathrm{HV}$ to $1600 \mathrm{HV}$ with the carburized layer thickness of about $150 \mu \mathrm{m}$ along the surface. 
They revealed that fine and homogeneous dispersion of hard carbide particles such as $\mathrm{TiC}$ and $\mathrm{V}_{4} \mathrm{C}_{3}$ found in the carburized layer able to improve wear resistance as well as fatigue life for more than two folds. Tsuji et al. carburized Ti6Al4V at $600{ }^{\circ} \mathrm{C}$ in a Ar gas conditioned furnace using $\mathrm{CH}_{4}-\mathrm{H}_{2}$ plasma for $1 \mathrm{hr}$ for improving hardness from $400 \mathrm{HV}$ to $600 \mathrm{HV}$ (Tsuji et al., 2009a). They also investigated the effects of combining plasma-carburizing and deep rolling on the notched surface microstructure and morphology, micro-hardness and notch fatigue life of Ti-6Al-4V alloy specimen in a laboratory at an ambient temperature. They reported that the notch root area of plasma-carburized specimen's surface roughness has been significantly improved by deep-rolling. This method effectively introduces compressive residual stress and work hardening in the substrate. Plasma-carburization with subsequent deep-rolling largely enhances the notch fatigue strength of specimen in comparison with untreated specimen. The developed compressive residual stress and work hardening zone influence the initial crack growth rate of deep-rolled carburized specimen. The thickness of this zone is approximately $350 \mu \mathrm{m}$ depth from the surface. However, the crack rapidly propagates toward the inside after it passes through this zone. They concluded that plasma-carburizing process combined with deep-rolling effectively improves the notch fatigue properties of Ti-6Al-4V alloy. Another researcher made an effort to investigate the plasticity effect on titanium alloy after being treated under gas carburization. Luo et al. carburized Ti6Al4V at $1050{ }^{\circ} \mathrm{C}$ in a vacuum furnace using $\mathrm{C}_{2} \mathrm{H}_{2}$ gas for $4 \mathrm{hrs}$ for improving the of hardness from $350 \mathrm{HV}$ to $778 \mathrm{HV}$ (Luo et al., 2011). TiC or also called titanium cermets were successfully formed on the surface. It was reported that the plasticity of the titanium cermets was slightly lower (10.86\%) than original titanium bare material. This indicates that the carburized titanium has significantly improved in fracture toughness as compared to typical ceramics material. They concluded that carburization is a way to produce titanium cermets efficiently which consists of hard surface, high toughness and plasticity. All these properties make titanium carbide as a potential candidate for artificial articulation material. In summary, the primary objective of gas carburizing is to produce carburized layer on the substrate in order to increase wear resistance property of titanium alloys. However, improvement in hardness introduces other issues such as reduction in plasticity and fatigue strength in the titanium substrate.

\subsection{Carburization by laser melting}

Laser carburizing technique is developed from laser surface hardening of steel. In a simple way, laser carburization can be defined as a process of using laser as a source of high energy to perform carburization. There are various types of laser carburizing methods where the categories are based on laser source, such as Neodymium Yttrium Lithium Fluoride (Nd:YLF), Neodymium Yttrium Aluminium Garnet (Nd:YAG), Titanium Sapphire (Ti:Sapphire), $\mathrm{CO}_{2}$ laser, etc. Laser carburizing process involves carbon diffusion into the metal substrate using laser irradiation. The typical source of carbon is graphite powder. Other type of powder such as $\mathrm{TiC}$ is also being used in laser melting technique to form carburized layer on titanium based materials. Fig. 3 shows a schematic diagram of laser melting working principle. This process involved heating of specimen through continuous or pulse wave laser irradiation, rapid melting, intermixing or diffusion of carbon particle, and rapid solidification of the pre-deposited alloying elements on substrate to form an alloyed zone or carburized layer. 


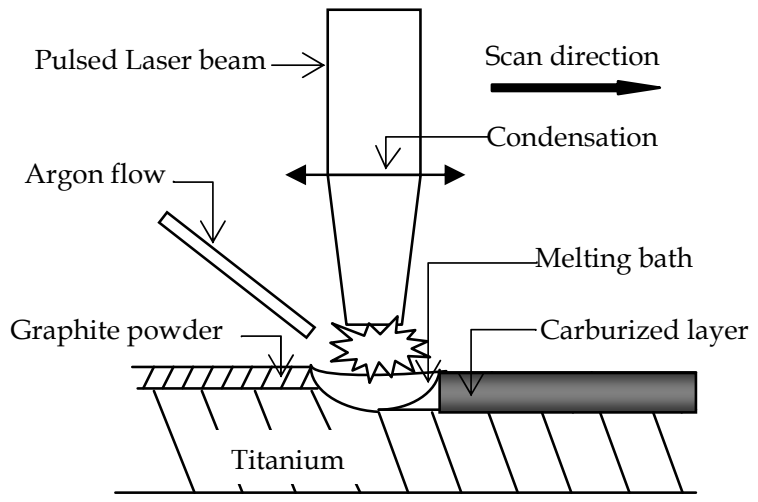

Fig. 3. Schematic diagram of typical pulsed laser carburization set up.

Investigations on laser carburizing technique were extended from steel to a-Titanium (Fouilland et al., 1997), commercial pure titanium (Courant et al., 2005), and biomedical grade titanium (Sampedro et al., 2011). Laser melting carburization produces thick coating ranged between one and several hundred micrometers depending on the irradiation conditions. Other carburizing methods are more suitable for producing thin film coating. Another advantage of this method compared to other techniques is that it's capability of coating complex substrate geometry and shape such as notches or grooves where through other methods very difficult to reach these inaccessible areas. Wide heat affected zone is a general issue for thermal or plasma method heating which leading to shape distortion. On the other hand, laser carburizing method is free from these disadvantages since an accurate focused heating on the work piece can be controlled easily. Other commonly controlled laser processing parameters are laser power $(\mathrm{W})$, scanning speed $(\mathrm{mm} / \mathrm{min})$, pulse/deposition time (ms), laser frequency $(\mathrm{Hz})$ and overlapping factor $(\%)$. The effects of these variables are investigated in terms of changes to the hardness, compositions, heat affected zone, pores, cracks and microstructure of the carburized zone. For instance, a group of researchers investigated the effect of processing time on the $\mathrm{TiC}$ microstructure formation on titanium alloy using Nd-YAG laser (Courant et al., 2005). They observed that the time ratio has a significant effect on the carburized microstructure. A lower time ratio caused an increase in pulse power leading to form a thick layer of melted zone with rich in carbon but free from graphite formation. In contrast, higher time ratio produces large amount of graphite formation in the melted zone which can act as a solid lubrication. This phenomenon shows the potential to reduce abrasive wear rate and hence increase the tribological performance of articulation implants. One group of researchers compared the effect of process parameters (laser power and scanning speed) on solidification of $\mathrm{TiC}$ microstructure using two different laser sources on Ti-6Al-4V substrate (Saleh et al., 2010). They found that TiC appears either in the form of dendrites or as particles located inside the grains and at the grain boundaries. This resulted significant increment in microhardness of the surface after carburizing process. They concluded that both Nd-YAG and the $\mathrm{CO}_{2}$ lasers able to produce macroscopically homogeneous microstructures of carburized layers. However, the former laser produces deeper carburized layer compared to the later. Recently, another group of workers studied pulse wave laser method (Nd-YAG laser) to form TiC layer on CP-Ti. They investigated the effect of process parameters (irradiated energy per length and pulse duration) on the 
microstructure as well as hardness of the substrate surface. It is noted that the microhardness of the surface increased 3-5 times higher than the base metal substrate when increasing the pulse duration. It is also observed that the microhardness of microstructure reduced by decreasing the irradiated energy per unit length of the material where irradiated energy can be reduced by increasing the process travel speed (Hamedi et al., 2011). In a summary, laser carburization is a potential route of strong surface hardening method with a short process time to increase the wear resistance property of the titanium alloys without affecting its bulk properties. This method provides hardest carbide layer compared to other two carburization techniques.

\section{Ion implantation and deposition}

Ion implantation or ion beam processing is a procedure in which ions of a material are accelerated in an electric field and bombarded into the solid substrate surface. Various ions such as oxygen, nitrogen, carbon, etc. can be implanted on any substrate material for a coating purpose to modify the substrate surface. When carbon is implanted on substrate material then the effect of the surface modification is similar to carburization. Similarly, this method also can be applicable for nitridation as well as oxidation. Two common types of ion implantation process are (i) Conventional beam line ion implantation and (ii) Plasma immersion ion implantation (PIII) method. The basic difference between the beam line ion implantation and plasma immersion ion implantation method is the target function. In beam line ion implantation, the target is totally isolated from the ion beam generation. In contrast, the target is an active part of the ion generation through bias voltage in PIII system (Savaloni et al., 2010). Fig. 4 shows the two typical types of ion implantation systems. The ion implantation phenomena started with the acceleration of ions and it directed towards a substrate (titanium in the present case) which is called target. The energy of the ions is usually in the range of several kilo electronvolt to few mega electronvolt. This level of energy could cause significant changes in the surface by the ions penetration. However, the energy of ions is selected carefully to avoid deep penetration inside the substrate. Therefore, the surface modifications are limited to the near-surface region and a depth of $1 \mu \mathrm{m}$ from the surface is normal (Rautray et al., 2011). In other words, bulk material properties will not be affected by the ion implantation process.

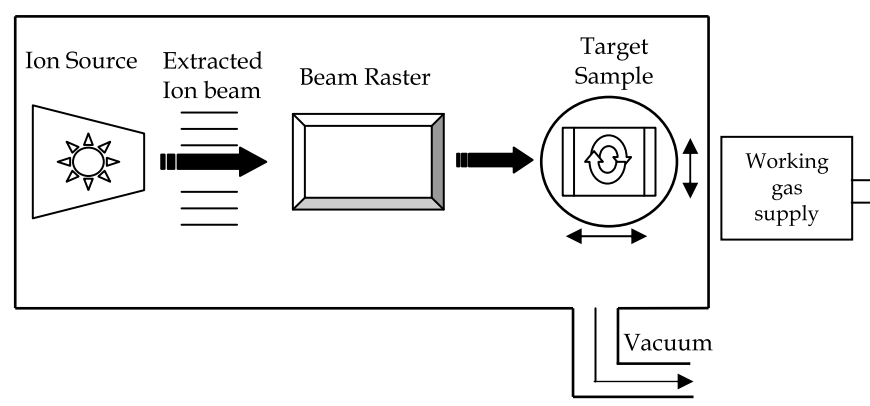

(a)

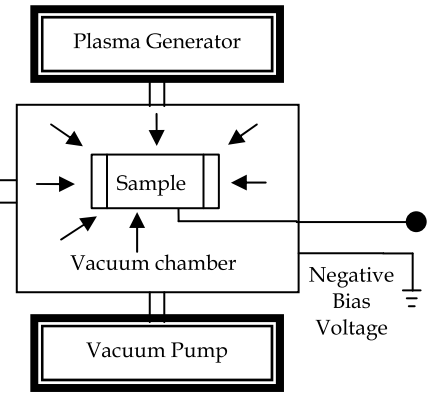

(b)

Fig. 4. Schematic diagram of (a) beam line ion implantation system and (b) PIII ion implantation system 
For instance, in carbon ion implantation process, the implanted carbon ions are limited either to form titanium carbides or carbon atoms with $\mathrm{C}-\mathrm{C}$ bonds near the surface. This may result in improvement of the mechanical properties as well as biocompatibility of titanium alloys. However, studies on the issue regarding corrosion resistance of $\mathrm{TiC}$ formation by ion implantation carburization are still underway. It is reported that a very high carbon ion dose of implantation $\left(10^{18} \mathrm{~cm}^{-2}\right)$ will reduce surface hardness of the titanium substrate (Viviente et al., 1999). The reaction between excess carbon and titanium produces mixed layer of graphite ( $\mathrm{C}-\mathrm{C}$ bonds) and $\mathrm{TiC}$ which cause reduction in hardness. In other study, a moderate dose of ion implantation from $5 \times 10^{15}$ to $1 \times 10^{17} \mathrm{~cm}^{-2}$ able to create nanocrystalline titanium carbide (TiC) layer which hardness of more than two folds on Ti-6Al-4V alloy substrate (Liu et al., 2004). Liu et al. also reported that the tribological properties of titanium alloys are significantly improved at ion implant doses of over $4 \times 10^{17} \mathrm{~cm}^{-2}$, producing friction coefficients of 0.2-0.3. Ion implantation method is free from some disadvantages of plasma process such as thick coating, different phases of mixed crystalline and low crystallinity which leads to delamination problem (Rautray et al., 2011). Effects of ion implantation process on wear resistance also have been studied by various researchers. Williams et al. investigated carbon ion implantation effect on the wear resistance of Ti-6Al$4 \mathrm{~V}$ alloys in a corrosive environment with the composition of $0.9 \% \mathrm{NaCl}$ or $0.9 \% \mathrm{NaCl}+$ $10 \%$ serum (Williams, 1985). Two-stage carbon ion implantation: $2.5 \times 10^{16} \mathrm{~cm}^{-2}$ at $35 \mathrm{kV}$ followed by $1.6 \times 10^{17} \mathrm{~cm}^{-2}$ at $50 \mathrm{kV}$ were carried out for the test. They revealed that ion implanted sample shows reduction in corrosion current by a factor of 100 compared to that untreated samples. A group of researchers investigated Ti-6Al-4V alloy's corrosion resistance after $80 \mathrm{kV}, 3 \times 10^{17} \mathrm{~cm}^{-2}$ carbon ion implantation (Zhang et al., 1991). They carried out examinations using electrochemical methods in two media: $0.5 \mathrm{M} \mathrm{H}_{2} \mathrm{SO}_{4}$ and $(\mathrm{HCl}+\mathrm{NaCl})$ solution $(\mathrm{pH}=0.1)$ at $25 \circ \mathrm{C}$. In both solutions, ion implanted samples show higher corrosion potential $\left(\mathrm{E}_{\mathrm{cor}}\right)$ than unimplanted samples. They also reported that the increment in the surface corrosion resistance was due to a durable solid passive layer formation. Other group of researchers experimented various carbon doses on the titanium alloy for evaluating corrosion resistance of $\mathrm{TiC}$ formation at energy of $100 \mathrm{keV}$. in $0.9 \% \mathrm{NaCl}$ solution at a temperature of $37^{\circ} \mathrm{C}$ (Krupa et al., 1999). They revealed that the corrosion resistance of titanium alloy improved significantly by producing a continuous solid nanocrystalline TiC layer when applying $1 \times 10^{17} \mathrm{C}^{+} \mathrm{cm}^{-2}$ of carbon dose or more. Another group of workers studied the formation of $\mathrm{TiC}$ on titanium alloy using PIII method by varying the deposition times (Baba et al., 2007). They concluded that the formation of TiC through ion implantation on titanium alloy depends on amount of carbon ion implantation which is proportional to ion implantation process time. Corrosion resistance on biomedical grade titanium alloy can also be improved by nitrogen ion implantation. It was reported that increasing of $\mathrm{N}^{+}$flux will influence the corrosion potential, corrosion current and passive current. These changes lead to initial increase in the corrosion resistance of the titanium alloy (Savaloni et al., 2010). Other group of researchers investigated the effect of process temperature and implantation time on the corrosion properties of Ti-6Al-4V. It was found that prolonged implantation times do not contribute to a major changes in corrosion resistance where process temperature does (Silva et al., 2010). They also reported that the best corrosion resistance achieved at $760{ }^{\circ} \mathrm{C}$ with $2 \mathrm{hr}$ processing time. Previous studies on PIII method basically focused on single non-metallic ion implantation to improve 
tribological properties such as hardness as well as corrosion resistance. However, in the recent development, it shows that the research interests in this method have been expanded to include implanting both metal and non-metallic ion simultaneously on titanium alloy. The main driving force of introducing this dual implantation method is to address the clinical and tribological issues concurrently. For example, $\mathrm{Ca}$ and $\mathrm{Mg}$ ion implanted into titanium alloy for increasing the bone integration (Kang et al., 2011). Ag and N ion have been used to have dual effects on titanium alloy (Li et al., 2011). Ag provides antibacterial effect and nitride layer (TiN) formed on the titanium surface increases wear and corrosion resistance. The ion implantation sequence in this dual method also has impact on the deposited particle size and distribution. In a summary, ion implantation method is more suitable for wear and corrosion resistance application. However, recent research trend on ion implantation shows the focus is not only on tribological issues but also on the effect in clinical aspects. Therefore, various metallic ions implantation on titanium alloy appear to be a future prospective research area.

\section{Conclusions}

Various surface modification methods used for improving properties of biomedical grade titanium and its alloys are discussed in this chapter. There are at least six (6) different methods available in the current practice. These are mechanical, chemical, physical, sol-gel, carburization and ion implantation. Oxidation and carburization methods are discussed in detail while the discussions on other methods are in brief.

Oxidation method modifies the titanium surface into various types of oxides. The main objective is to produce porous oxide structure for promoting cell growth and cell attachment. There are cases where corrosion and wear resistance are also improved by applying this technique. The recent trend shows that the oxide layer formed on the titanium substrate serves as a basis for growing hydroxyapatite layer to increase bioactivity.

Carburization is mainly used to improve wear resistance by increasing titanium surface hardness via thermal, gas and laser melting methods. Hardness of titanium carbide layer formed through these methods varies from 1.5 to 5 times as compared to bare material. Higher hardness of carbide layer assists to increase wear and corrosion resistance of implant surface.

Ion implantation method provides better wear and corrosion resistance than other thermal surface modification techniques. In the recent trend, ion implantation technique is found to provide dual effects concurrently such as wear resistance and antibacterial effect.

Generally, it is observed that the overall trends of surface modification methods seem to shift from the use of conventional source (chemical, induction heater and gas) to the application of advanced technology (electrolyte based, laser, plasma and ion). This could be due to the low efficiency of conventional methods that require longer time and huge amount of energy. The works on surface modifications also appear to expand from focusing on tribological issues such as wear resistance, corrosion resistance and hardness of modified layer to clinical issues such as cell growth, cell attachment and antibacterial effects. These developments demand newer technologies in the future for providing solutions of dual issues simultaneously, i.e. tribological and clinical. 


\section{Acknowledgements}

Authors would like to express highest gratitude to Ministry of Higher Education (MOHE)and Ministry of Science, Technology and Innovation (MOSTI) for providing grant to conduct this study via vote numbers Q.J130000.7124.02H60, 78611 and 79374. Authors also would like to thank the Faculty of Mechanical Engineering, UTM for providing their facilities to carry out this study.

\section{Nomenclature}

BCP Biphasic Calcium Phosphates

CVD Chemical Vapour Deposition

CP Commercial Pure

DGUN Detonation Gun

HVOF High Velocity Oxygen Fuel spraying

HA Hydroxyapatite

LSA Laser Surface Alloying

MAO Micro Arc Oxidation

Nd:YAGNeodymium Yttrium Aluminium Garnet

Nd:YLF Neodymium Yttrium Lithium Fluoride

PIII Plasma Immersion Ion Implantation

SBF Simulated Body Fluid

\section{References}

American Society for Testing and Materials (1997). ASTM standard B600, Philadelphia, American Society for Testing and Materials.

Andrew, W. B., Chandrasekaran, Margam (2004). Service characteristics of biomedical materials and implants, London, Imperial College Press.

Baba, K., Hatada, R., Flege, S., Kraft, G. \& Ensinger, W. (2007). Formation of thin carbide films of titanium and tantalum by methane plasma immersion ion implantation. Nuclear Instruments and Methods in Physics Research Section B: Beam Interactions with Materials and Atoms, vol.257, pp.746-749

Bharathy, P. V., Nataraj, D., Chu, P. K., Wang, H., Yang, Q., Kiran, M. S. R. N., SilvestreAlbero, J. \& Mangalaraj, D. (2010). Effect of titanium incorporation on the structural, mechanical and biocompatible properties of DLC thin films prepared by reactive-biased target ion beam deposition method. Applied Surface Science, vol.257, pp.143-150

Biswas, A. \& Dutta Majumdar, J. (2009). Surface characterization and mechanical property evaluation of thermally oxidized Ti-6Al-4V. Materials Characterization, vol.60, pp.513-518

Bloyce, A., Morton,P., Bell,T. (1994). ASM Handbook, OH, ASM International

Bloyce, A., Qi, P. Y., Dong, H. \& Bell, T. (1998). Surface modification of titanium alloys for combined improvements in corrosion and wear resistance. Surface and Coatings Technology, vol.107, pp.125-132 
Borgioli, F., Galvanetto, E., Iozzelli, F. \& Pradelli, G. (2005). Improvement of wear resistance of Ti-6Al-4V alloy by means of thermal oxidation. Materials Letters, vol.59, pp.21592162

Brinker, C. J. S., G.W. (1990). The Physics and Chemistry of Sol-Gel Processing, San Diego, American Press.

Cáceres, D., Munuera, C., Ocal, C., Jiménez, J. A., Gutiérrez, A. \& López, M. F. (2008). Nanomechanical properties of surface-modified titanium alloys for biomedical applications. Acta Biomaterialia, vol.4, pp.1545-1552

Cimenoglu, H., Gunyuz, M., Kose, G. T., Baydogan, M., Uğurlu, F. \& Sener, C. (2011). Microarc oxidation of Ti6Al4V and Ti6Al7Nb alloys for biomedical applications. Materials Characterization, vol.62, pp.304-311

Citeau, A., Guicheux, J., Vinatier, C., Layrolle, P., Nguyen, T.P., Pilet, P., Daculsi, G. (2005). In vitro biological effects of titanium rough surface obtained by calcium phosphate grid blasting. Biomaterials, vol.26, pp.157-165

Cochepin, B., Gauthier, V., Vrel, D. \& Dubois, S. (2007). Crystal growth of TiC grains during SHS reactions. Journal of Crystal Growth, vol.304, pp.481-486

Courant, B., Hantzpergue, J. J., Avril, L. \& Benayoun, S. (2005). Structure and hardness of titanium surfaces carburized by pulsed laser melting with graphite addition. Journal of Materials Processing Technology, vol.160, pp.374-381

Curran, J. A., Clyne, T. W. (2005). Thermo-physical properties of plasma electrolytic oxide coatings on aluminium. Surface and Coatings Technology, vol.199, pp.168-176

Dearnley, P. A., Dahm, K. L. \& Çimenoğlu, H. (2004). The corrosion-wear behaviour of thermally oxidised CP-Ti and Ti-6Al-4V. Wear, vol.256, pp.469-479

Dunleavy, C. S., Golosnoy, I. O., Curran, J. A. \& Clyne, T. W. (2009). Characterisation of discharge events during plasma electrolytic oxidation. Surface and Coatings Technology, vol.203, pp.3410-3419

Fini, M., Savarino, L., Aldini, N.N., Martini, L., Giaveresi, G., Rizzi, G., Martini, D., Ruggeri, A., Giunti, A., Giardino, R. (2003). Biomechanical and histomorphometric investigation on two morphologically differing titanium surfaces with and without frluorohydroxyapatite coating: an experimental study in sheep tibiae. Biomaterials, vol.24, pp.3183-3192

Fouilland, P. L., Ettaqi, S., Benayoun, S. \& Hantzpergue, J. J. (1997). Structural and mechanical characterization of $\mathrm{Ti} / \mathrm{TiC}$ cermet coatings synthesized by laser melting. Surface and Coatings Technology, vol.88, pp.204-211

Gbureck, U. M., A. Probst, J. Thull, R. (2003). Tribochemical structuring and coating of implant metal surfaces with titanium oxide and hydroxyapatite layers. Materials Science and Engineering C, vol.23, pp.461-465

Geetha, M. S., A.K.R. Asokamani and Gogia, A.K. (2009). Ti Based Biomaterials: the Ultimate Choice for Orthopaedic Implants. Progress in Materials Science, vol.54, pp.397-425

Gotoh, Y., Fujimura, K., Koike, M., Ohkoshi, Y., Nagura, M., Akamatsu, K. \& Deki, S. (2001). Synthesis of titanium carbide from a composite of TiO2 nanoparticles/methyl cellulose by carbothermal reduction. Materials Research Bulletin, vol.36, pp.22632275 
Guleryuz, H. \& Cimenoglu, H. (2005). Surface modification of a Ti-6Al-4V alloy by thermal oxidation. Surface and Coatings Technology, vol.192, pp.164-170

Gutiérrez, A., Munuera, C., López, M. F., Jiménez, J. A., Morant, C., Matzelle, T., Kruse, N. \& Ocal, C. (2006). Surface microstructure of the oxide protective layers grown on vanadium-free Ti alloys for use in biomedical applications. Surface Science, vol.600, pp.3780-3784

Gutiérrez, A., Paszti, F., Climent, A., Jimenez, J. A. \& López, M. F. (2008). Comparative study of the oxide scale thermally grown on titanium alloys by ion beam analysis techniques and scanning electron microscopy. Journal of Materials Research vol.23, pp.2245-2253

Hamedi, M. J., Torkamany, M. J. \& Sabbaghzadeh, J. (2011). Effect of pulsed laser parameters on in-situ TiC synthesis in laser surface treatment. Optics and Lasers in Engineering, vol.49, pp.557-563

Han, Y., Hong, S. H. \& Xu, K. W. (2002). Porous nanocrystalline titania films by plasma electrolytic oxidation. Surface and Coatings Technology, vol.154, pp.314-318

Hollinger, S. A. G. A. J. O. 2006. An introduction to biomaterials, Florida, Tailor \& Francis.

Huang, H., Winchester, K. J., Suvorova, A., Lawn, B. R., Liu, Y., Hu, X. Z., Dell, J. M. \& Faraone, L. (2006). Effect of deposition conditions on mechanical properties of lowtemperature PECVD silicon nitride films. Materials Science and Engineering: A, vol.435-436, pp.453-459

Ishizawa, H., Ogino, M. (1995). Characterization of thin hydroxyapatite layers formed on anodic titanium oxide films containing $\mathrm{Ca}$ and $\mathrm{P}$ by hydrothermal treatment. Journal of Biomedical Materials Research Part: A, vol.29, pp. 1071-1079

Jin, F., Chu, P. K., Wang, K., Zhao, J., Huang, A. \& Tong, H. (2008). Thermal stability of titania films prepared on titanium by micro-arc oxidation. Materials Science and Engineering: A, vol.476, pp.78-82

Kang, B.-S., Sul, Y.-T., Jeong, Y., Byon, E., Kim, J.-K., Cho, S., Oh, S.-J. \& Albrektsson, T. (2011). Metal plasma immersion ion implantation and deposition (MePIIID) on screw-shaped titanium implant: The effects of ion source, ion dose and acceleration voltage on surface chemistry and morphology. Medical Engineering $\mathcal{E}$ Physics vol.33, pp.730-738

Khanna, A. S. (2004). Introduction to High Temperature Oxidation and Corrosion, California, ASM International.

Kim, H. M. M., F. Kokubo, T. Nakamura,T. (1996). Preparation of bioactive Ti and its alloys via simple chemical surface treatment. Journal of Biomedical Materials Research Part A, vol. 32, pp. 409-417

Kim, H. W., Koh,Y.H., Li, L.H., Lee,S., Kim, H.E. (2004). Hydroxyapatite coating on titanium substrate with titania Buffet layer processed by sol-gel method. Biomaterials, vol.25, pp. $2533-2538$

Kim, M. S., Ryu, J.J., Sung, Y.M. (2007). One-step approach for nano-crystalline hydroxyapatite coating on titanium via micro-arc oxidation. Electrochemical Communication, vol.9, pp.1886-1891

Kim, T.-S., Park, Y.-G. \& Wey, M.-Y. (2003). Characterization of Ti-6Al-4V alloy modified by plasma carburizing process. Materials Science and Engineering A, vol.361, pp.275-280 
Kofstad, P. 1988. High Temperature Corrosion, New York, Elsevier Applied Science Publisher Ltd.

Krishna, D. S. R. \& Sun, Y. (2005). Thermally oxidised rutile-TiO2 coating on stainless steel for tribological properties and corrosion resistance enhancement. Applied Surface Science, vol.252, pp.1107-1116

Krupa, D., Jezierska, E., Baszkiewicz, J., Wierzchoń, T., Barcz, A., Gawlik, G., Jagielski, J., Sobczak, J. W., Biliński, A. \& Larisch, B. (1999). Effect of carbon ion implantation on the structure and corrosion resistance of OT-4-0 titanium alloy. Surface and Coatings Technology, vol.114, pp.250-259

Kumar, S., Narayanan, T. S. N. S., Raman, S. G. S. \& Seshadri, S. K. (2009). Thermal oxidation of CP-Ti: Evaluation of characteristics and corrosion resistance as a function of treatment time. Materials Science and Engineering: C, vol.29, pp.19421949

Kumar, S., Narayanan, T. S. N. S., Raman, S. G. S. \& Seshadri, S. K. (2010a). Thermal oxidation of $\mathrm{CP} \mathrm{Ti}$-- An electrochemical and structural characterization. Materials Characterization, vol.61, pp.589-597

Kumar, S., Sankara Narayanan, T. S. N., Ganesh Sundara Raman, S. \& Seshadri, S. K. (2010b). Thermal oxidation of Ti6Al4V alloy: Microstructural and electrochemical characterization. Materials Chemistry and Physics, vol.119, pp.337-346

Lausmaa, J., Brunette , D.M., Tengvall , P. Textor , M. Thomsen , P. 2001. Titanium in Medicine, Berlin, Springer.

Lee, J. H., Thadhani, N. N. (1997). Reaction synthesis mechanism in dynamically densified Ti + C powder compacts. Scripta Materialia, vol.37, pp.1979-1985

Li, J., Qiao, Y., Ding, Z. \& Liu, X. (2011). Microstructure and properties of Ag/N dual ions implanted titanium. Surface and Coatings Technology, vol.205, pp.5430-5436

Liu, X., Chu, P. K. \& Ding, C. (2004). Surface modification of titanium, titanium alloys, and related materials for biomedical applications. Materials Science and Engineering: $R$ : Reports, vol.47, pp.49-121

Liu, X., Chu, P. K. \& Ding, C. (2010). Surface nano-functionalization of biomaterials. Materials Science and Engineering: R: Reports, vol.70, pp.275-302

López, M. F., Gutiérrez, A. \& Jiménez, J. A. (2001). Surface characterization of new non-toxic titanium alloys for use as biomaterials. Surface Science, vol.482-485, Part 1, pp.300305

López, M. F., Gutiérrez, A., Jiménez, J. A., Martinesi, M., Stio, M. \& Treves, C. (2010). Thermal oxidation of vanadium-free $\mathrm{Ti}$ alloys: An X-ray photoelectron spectroscopy study. Materials Science and Engineering: C, vol.30, pp.465-471

López, M. F., Jiménez, J. A. \& Gutiérrez, A. (2003). Corrosion study of surface-modified vanadium-free titanium alloys. Electrochimica Acta, vol.48, pp.1395-1401

López, M. F., Soriano, L., Palomares, F. J., Nchez-Agudo, M. S., Fuentes, G. G., Gutierrez, A. \& Nez3, J. A. J. (2002). Soft x-ray absorption spectroscopy study of oxide layers on titanium alloys. Surface and Interface Analysis vol.33, pp.570-576

Luo, Y., Ge, S.-R. \& Jin, Z.-M. (2009). Wettability modification for biosurface of titanium alloy by means of sequential carburization. Journal of Bionic Engineering, vol.6, pp. $219-223$ 
Luo, Y., Jiang, H., Cheng, G. \& Liu, H. (2011). Effect of carburization on the mechanical properties of biomedical grade titanium alloys. Journal of Bionic Engineering, vol.8, pp.86-89

Maitre, A., Tetard, D. \& Lefort, P. (2000). Role of some technological parameters during carburizing titanium dioxide. Journal of the European Ceramic Society, vol.20, pp.15-22

Morant, C., López, M. F., Gutiérrez, A. \& Jiménez, J. A. (2003). AFM and SEM characterization of non-toxic vanadium-free Ti alloys used as biomaterials. Applied Surface Science, vol.220, pp.79-87

Munuera, C., Matzelle, T. R., Kruse, N., López, M. F., Gutiérrez, A., Jiménez, J. A. \& Ocal, C. (2007). Surface elastic properties of Ti alloys modified for medical implants: A force spectroscopy study. Acta Biomaterialia, vol.3, pp.113-119

Nanci, A. W., J.D. Peru, L.Brunet,P. Sharma,V. Zalzal,S. Mckee, M.D. (1998). Journal of Biomedical Materials Research, vol.40, pp.324

Okamoto, Z., Hoshika, H., Yakushiji, M. (2001). Heat Treatment, vol.40, pp.88

Piveteau, L.-D., Brunette, D.M., Tengvall,P. , Textor,M., Thomsen, P. 2001. Titanium in Medicine, Berlin, Springer.

Prabhudev, K. H. 1988. Handbook of Heat Treatment of Steels, New Delhi, Tata McGraw-Hill Publishing Company Ltd.

Rastkar, A. R. \& Bell, T. (2005). Characterization and tribological performance of oxide layers on a gamma based titanium aluminide. Wear, vol.258, pp.1616-1624

Rautray, T. R., Narayanan, R. \& Kim, K. H. (2011). Ion implantation of titanium based biomaterials. Progress in Materials Science, vol.56, pp.1137-1177

Ravelingien, M., Hervent, A.-S., Mullens, S., Luyten, J., Vervaet, C. \& Remon, J. P. (2010). Influence of surface topography and pore architecture of alkali-treated titanium on in vitro apatite deposition. Applied Surface Science, vol.256, pp.3693-3697

Robert, H. T., Dell, K. A. , Leo, A. 1994. Manufacturing Processes Reference Guide, New York, Industrial Press Inc.

S. Izman, Abdul-Kadir, M. R., Anwar, M., Nazim, E. M., L.Y.Kuan \& E.K.Khor (2011a). Effect Of Pickling Process On Adhesion Strength Of Ti Oxide Layer On Titanium Alloy Substrate. Advanced Materials Research, vol.146-147, pp.1621-1630

S. Izman, Abdul-Kadir, M. R., Anwar, M., Nazim, E. M., Nalisa, A. \& M.Konneh (2011b). Effect of carburization process on adhesion strength of Ti carbide layer on titanium alloy substrate. Advanced Materials Research, vol.197-198, pp.219-224

S. Izman, Shah, A., Abdul-Kadir, M. R., Nazim, E. M., Anwar, M., Hassan, M. A. \& Safari, H. (2011c). Effect Of Thermal Oxidation Temperature On Rutile Structure Formation Of Biomedical TiZrNb Alloy Advanced Materials Research,

Saleh, A. F., Abboud, J. H. \& Benyounis, K. Y. (2010). Surface carburizing of Ti-6Al-4V alloy by laser melting. Optics and Lasers in Engineering, vol.48, pp.257-267

Sampedro, J., Pérez, I., Carcel, B., Ramos, J. A. \& Amigó, V. (2011). Laser Cladding of TiC for Better Titanium Components. Physics Procedia, vol.12, Part A, pp.313-322

Savaloni, H., Khojier, K. \& Torabi, S. (2010). Influence of N+ ion implantation on the corrosion and nano-structure of Ti samples. Corrosion Science, vol.52, pp.1263-1267

Sen, W., Sun, H., Yang, B., Xu, B., Ma, W., Liu, D. \& Dai, Y. (2010). Preparation of titanium carbide powders by carbothermal reduction of titania/charcoal at vacuum 
condition. International Journal of Refractory Metals and Hard Materials, vol.28, pp.628-632

Shin, Y.-K., Chae, W.-S., Song, Y.-W. \& Sung, Y.-M. (2006). Formation of titania photocatalyst films by microarc oxidation of $\mathrm{Ti}$ and $\mathrm{Ti}-6 \mathrm{Al}-4 \mathrm{~V}$ alloys. Electrochemistry Communications, vol.8, pp.465-470

Silva, G., Ueda, M., Otani, C., Mello, C. B. \& Lepienski, C. M. (2010). Improvements of the surface properties of Ti6Al4V by plasma based ion implantation at high temperatures. Surface and Coatings Technology, vol.204, pp.3018-3021

Sobieszczyk, S. (2010a). Surface modifications of Ti and its alloys. Advances in Materials Sciences, vol.10, pp.29-42

Sobieszczyk, S. (2010b). Surface Modifications of Ti and its Alloys. Advances in Materials Sciences, vol.10, pp.29-42

Song, W. H., Jun,Y.K., Han,Y., Hong, S.H. (2004). Biomimetic apatite coatings on micro-arc oxidized titania. Biomaterials, vol.25, pp.3341-3349

Takebe, J., Itoh, S., Okada, J., Ishibashi, K. (2000). Anodic oxidation and hydrothermal treatment of titanium results in a surface that causes increased attachment and altered cytoskeletal morphology of rat bone marrow stromal cells in vitro. Journal of Biomedical Materials Research, vol.51, pp. 398-407

Takeuchi, M. A., Y. Yoshida,Y. Nakayama,Y. Okazaki,M. Kagawa,Y. (2003). Acid pretreatment of titanium implants. Biomaterials, vol.24, pp.1821-1827

Tsuji, N., Tanaka, S. \& Takasugi, T. (2009a). Effect of combined plasma-carburizing and deep-rolling on notch fatigue property of Ti-6Al-4V alloy. Materials Science and Engineering: A, vol.499, pp.482-488

Tsuji, N., Tanaka, S. \& Takasugi, T. (2009b). Effects of combined plasma-carburizing and shot-peening on fatigue and wear properties of Ti-6Al-4V alloy. Surface and Coatings Technology, vol.203, pp.1400-1405

Viviente, J. L., Garcia, A., Loinaz, A.,Alonso, F., on Ate, J.I. (1999). Carbon layers formed on steel and Ti alloys after ion implantation of C+ at very high doses. Vacuum, vol.52, pp.141-146

Wang, D. G., Chen, C. Z., Ma, J. \& He, T. (2011). Microstructure evolution of sol-gel HA films. Applied Surface Science, vol.257, pp.2592-2598

Weimer, A. W. 1997. Carbide, nitride and boride materials-synthesis and processing, London, Chapman \& Hall.

Williams, J. M., Buchanan, R.A., Rigney, E.D. (1985). In: Proceedings of the ASM conference on applications of ion plating and ion implantation to materials, Atlanta,GA, pp. 141.

Wojciech, S. (2011). Preliminary investigations on the anodic oxidation of $\mathrm{Ti}-13 \mathrm{Nb}-13 \mathrm{Zr}$ alloy in a solution containing calcium and phosphorus. Electrochimica Acta, vol.56, pp.9831-9837

Wu, S. K., Lee, C. Y. \& Lin, H. C. (1997). A study of vacuum carburization of an equiatomic TiNi shape memory alloy. Scripta Materialia, vol.37, pp.837-842

Yan, W. \& Wang, X. X. (2004). Surface hardening of titanium by thermal oxidation. Journal of Materials Science, vol.39, pp.5583-5585

Yang, B., Uchida, M., Kim, H.-M., Zhang, X. \& Kokubo, T. (2004). Preparation of bioactive titanium metal via anodic oxidation treatment. Biomaterials, vol.25, pp.1003-1010 
Yao, Z. P., Gao, H.H, Jiang, .Z.H., Wang,F.P. (2008). Structure and properties of $\mathrm{ZrO}_{2}$ ceramic coatings on AZ91D Mg alloy by plasma electrolytic oxidation. Journal of American Ceramic Society, vol.91, pp.555-558

Yerokhin, A. L., Nie,X., Leyland, A., Matthews,A., Dowey,S.J. (1999). Plasma electrolysis for surface engineering. Surface and Coatings Technology, vol.122, pp.73-93

Yin, X., Gotman, I., Klinger, L. \& Gutmanas, E. Y. (2005). Formation of titanium carbide on graphite via powder immersion reaction assisted coating. Materials Science and Engineering A, vol.396, pp.107-114

Zhang, D., Yu, W., Wang, Z. \& Dong, R. (1991). In: Corrosion control 7th APCCC China, China, pp. 793.

Zhao, B. H., Lee, I.S., Han,I.H., Park,J.C.,Chung, S.M. (2007). Current Applied Physics, vol.7S1, pp.e6-e10

Zhu, X., Kim, K.-H. \& Jeong, Y. (2001). Anodic oxide films containing Ca and P of titanium biomaterial. Biomaterials, vol.22, pp.2199-2206 


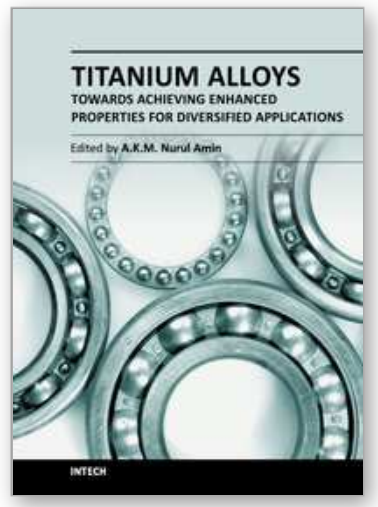

\author{
Titanium Alloys - Towards Achieving Enhanced Properties for \\ Diversified Applications \\ Edited by Dr. A.K.M. Nurul Amin
}

ISBN 978-953-51-0354-7

Hard cover, 228 pages

Publisher InTech

Published online 16, March, 2012

Published in print edition March, 2012

The first section of the book includes the following topics: fusion-based additive manufacturing (AM) processes of titanium alloys and their numerical modelling, mechanism of ?-case formation mechanism during investment casting of titanium, genesis of gas-containing defects in cast titanium products. Second section includes topics on behavior of the (?+?) titanium alloys under extreme pressure and temperature conditions, hot and super plasticity of titanium (? + ?) alloys and some machinability aspects of titanium alloys in drilling. Finally, the third section includes topics on different surface treatment methods including nanotube-anodic layer formation on two phase titanium alloys in phosphoric acid for biomedical applications, chemico-thermal treatment of titanium alloys applying nitriding process for improving corrosion resistance of titanium alloys.

\title{
How to reference
}

In order to correctly reference this scholarly work, feel free to copy and paste the following:

S. Izman, Mohammed Rafiq Abdul-Kadir, Mahmood Anwar, E.M. Nazim, R. Rosliza, A. Shah and M.A. Hassan (2012). Surface Modification Techniques for Biomedical Grade of Titanium Alloys: Oxidation, Carburization and Ion Implantation Processes, Titanium Alloys - Towards Achieving Enhanced Properties for Diversified Applications, Dr. A.K.M. Nurul Amin (Ed.), ISBN: 978-953-51-0354-7, InTech, Available from: http://www.intechopen.com/books/titanium-alloys-towards-achieving-enhanced-properties-for-diversifiedapplications/surface-modification-techniques-for-biomedical-grade-of-titanium-alloys-oxidation-carburizationand-

\section{INTECH}

open science | open minds

\section{InTech Europe}

University Campus STeP Ri

Slavka Krautzeka 83/A

51000 Rijeka, Croatia

Phone: +385 (51) 770447

Fax: +385 (51) 686166

www.intechopen.com

\section{InTech China}

Unit 405, Office Block, Hotel Equatorial Shanghai

No.65, Yan An Road (West), Shanghai, 200040, China

中国上海市延安西路65号上海国际贵都大饭店办公楼405单元

Phone: +86-21-62489820

Fax: $+86-21-62489821$ 
(C) 2012 The Author(s). Licensee IntechOpen. This is an open access article distributed under the terms of the Creative Commons Attribution 3.0 License, which permits unrestricted use, distribution, and reproduction in any medium, provided the original work is properly cited. 